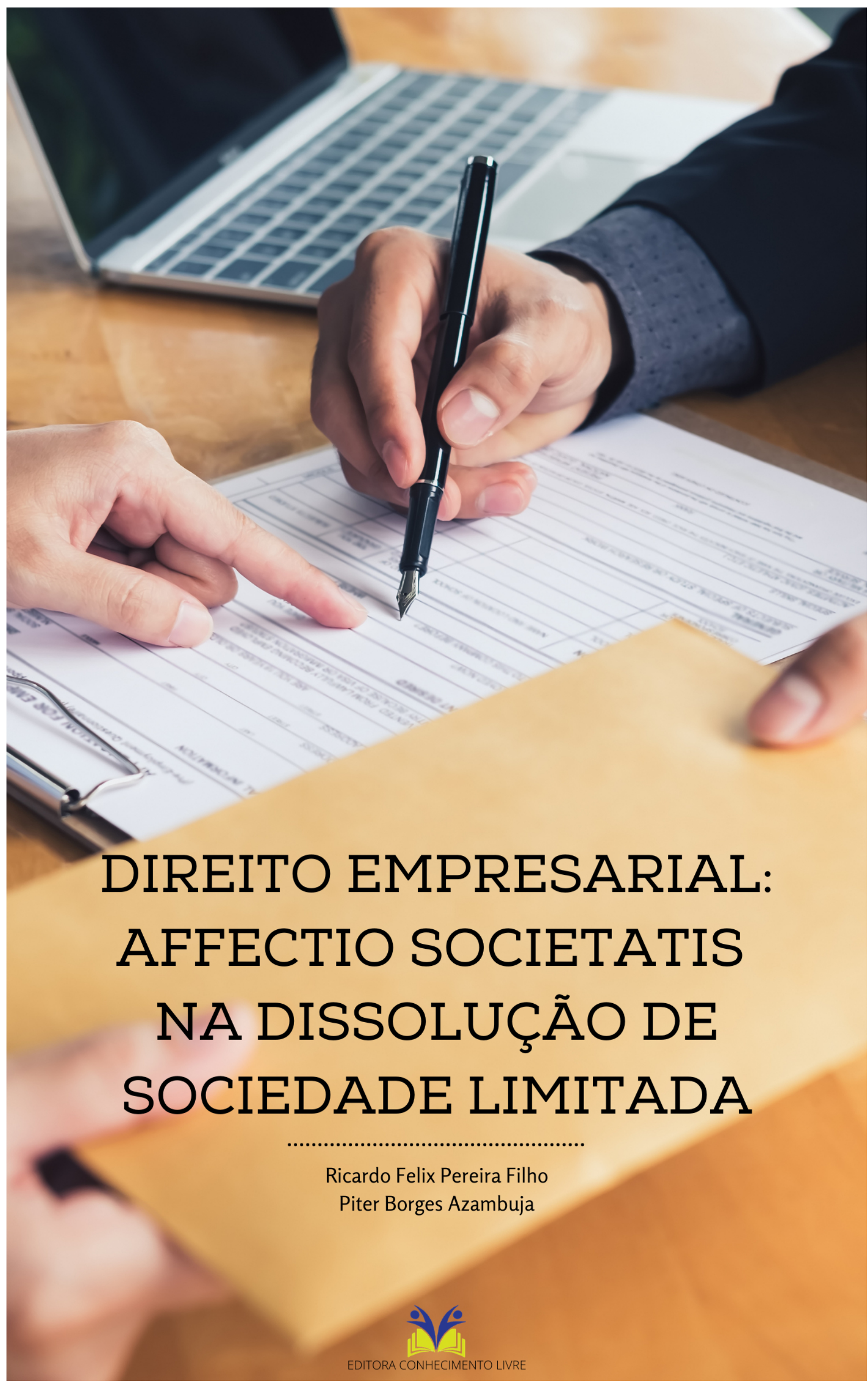


Ricardo Felix Pereira Filho

Piter Borges Azambuja

Direito Empresarial: Affectio societatis na dissolução de sociedade limitada

$1^{\text {a }}$ ed.

Piracanjuba-GO

Editora Conhecimento Livre

Piracanjuba-GO 
$1^{\mathrm{a}} \mathrm{ed}$

\section{Dados Internacionais de Catalogação na Publicação (CIP)}

Pereira Filho, Ricardo Felix
P436D Direito Empresarial: Affectio societatis na dissolução de sociedade limitada
/ Ricardo Felix Pereira Filho. Piter Borges Azambuja. - Piracanjuba-GO
Editora Conhecimento Livre, 2021
54 f:: il
DOI: 10.37423/2021.edc1245
ISBN: 978-65-89145-87-5
Modo de acesso: World Wide Web
Incluir Bibliografia
1. affectio-societatis 2. dissolução 3. sociedade I. Pereira Filho, Ricardo Felix II. Azambuja, Piter
Borges III. Título

https://doi.org/10.37423/2021.edc1245

O conteúdo dos artigos e sua correção ortográfica são de responsabilidade exclusiva dos seus respectivos autores. 


\section{EDITORA CONHECIMENTO LIVRE}

\section{Corpo Editorial}

Dr. João Luís Ribeiro Ulhôa

Dra. Eyde Cristianne Saraiva-Bonatto

MSc. Anderson Reis de Sousa

$\underline{\text { MSc. Frederico Celestino Barbosa }}$

MSc. Carlos Eduardo de Oliveira Gontijo

MSc. Plínio Ferreira Pires

Editora Conhecimento Livre

Piracanjuba-GO 
Direito Empresarial: Affectio societatis na dissolução de sociedade limitada

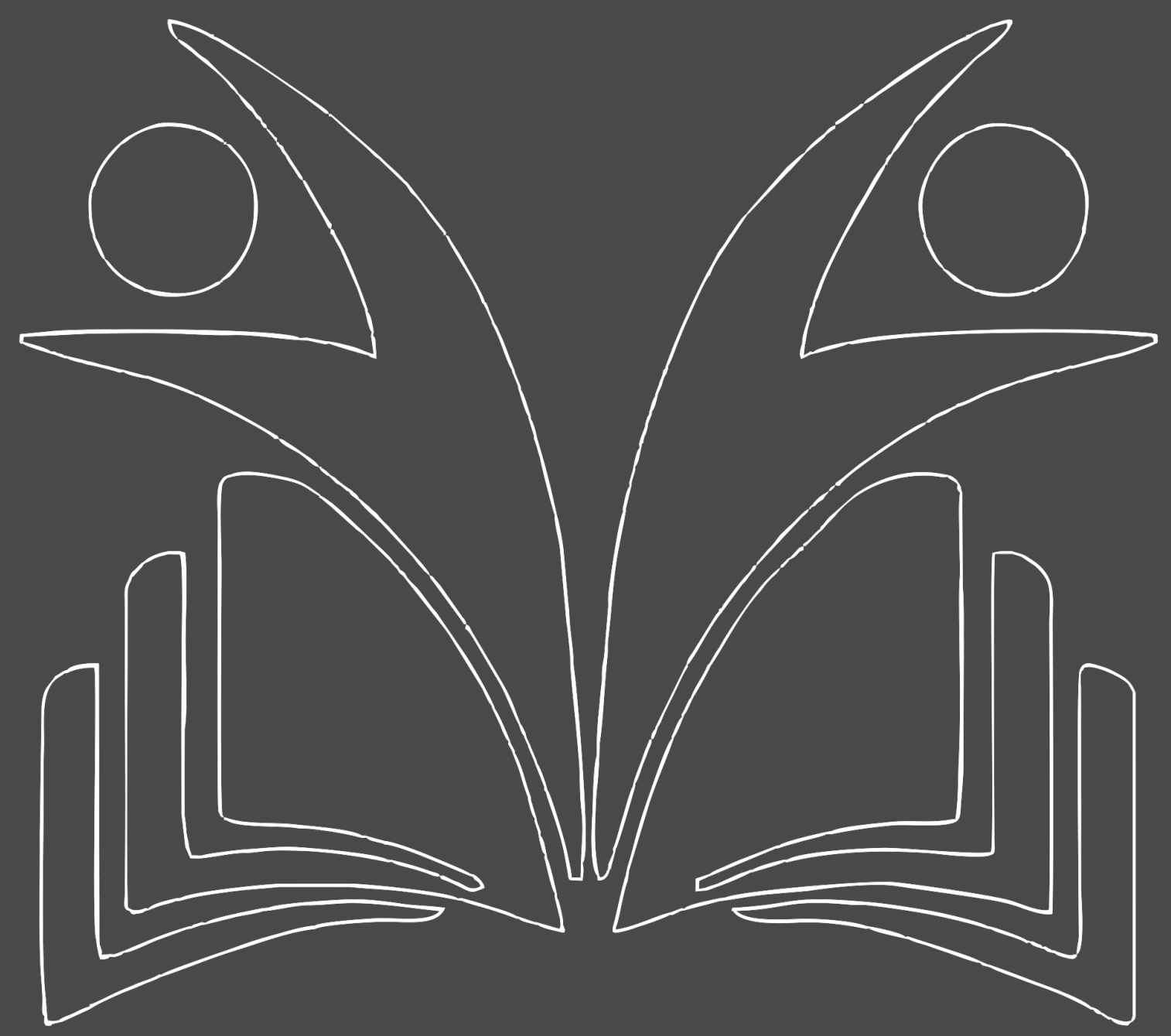




\section{Affectio Societatis Na Dissolução De Sociedade Limitada}

\section{AGRADECIMENTOS}

Inicialmente agradeço a Deus por todas as oportunidades que foram proporcionadas neste caminho que fora trilhado, por encontrar nele diariamente força e paciência.

À minha família, pelo apoio e compreensão, especialmente, a Alessandra Sousa Siqueira, Washington Sousa Siqueira e Gasparina Cornélio dos Reis pelo apoio, carinho e dedicação, pois sempre estiveram presentes aconselhando e incentivando a perseguir minhas metas.

A meus pais, Ricardo Felix Pereira e Enilsa dos Reis Felix, por todo o amor e por nunca medirem esforços para a conclusão dessa etapa da minha vida.

O meu magnificente orientador prof. Piter Borges Azambuja, por todo respeito, dedicação, paciência a mim durante e fora das orientações e por incentivar a investir na presente temática.

Ao ilustre prof. Leonardo Martins Pereira, pelas orientações e aconselhamento na matéria de TCC I, que colaboraram demasiado com o início e desenvolvimento para esta pesquisa, pela sua dedicatória a seus alunos e orientandos.

A todos os amigos e colegas que conviveram ou ainda convivem comigo, pelas contribuições diretas ou indiretas para meu progresso, em particular, Douglas Silva de Macedo, Jose Dias Assis Neto, Larissa Aparecida Silva Rodrigues, Danillo Reis da Mata, Daniel Silva Gonçalves e Cloves Ferreira de Souza Filho, pela presença e amizade.

Por fechamento, meu respeito, gratidão e considerações a todos os professores do curso de Direito da Universidade, profissionais de prestigio, que captam o apreço dos alunos, sempre dispostos a sanar dúvidas e guiar-nos por esse ciclo da vida. Gratidão imensurável. Obrigado a todos. 


\section{Affectio Societatis Na Dissolução De Sociedade Limitada}

Resumo: A presente monografia possui a temática sobre dissolução parcial de sociedade limitada e busca responder ao seguinte problema: O fim da affectio societatis legitima a dissolução parcial ou total de sociedade limitada? Com o objetivo em especifico de analisar a affectio societatis como hipótese e fundamento para dissolução de sociedade. Assim os sócios ou o sócio utiliza do argumento da quebra da affectio societatis para resolver a sociedade perante o sócio que desejam excluir. Acontece que na devida ação de dissolução não é apenas observado o argumento do rompimento da affectio societatis como também outro elemento. Para atingir a finalidade disserta ainda sobre preceitos de sociedades, os tipos de sociedade com responsabilidade limitada e causas de dissolução. Foi empregue o método dedutivo, servindo-se de doutrinas, jurisprudência e legislação para o desenvolvimento do estudo. Deste modo, na conclusão da pesquisa, demonstrará que o affectio societatis é causa de dissolução, porém necessário trazer a juízo fatos, fundamentos e provas do alegado rompimento que motivem uma indispensável dissolução de sociedade.

Palavras Chave: Affectio Societatis. Dissolução. Sociedade. Sócio. 


\section{Sumário}

INTRODUÇÃO

2. DAS DISPOSIÇÕES GERAIS DE SOCIEDADE.

2.1. DIREITO SOCIETÁRIO . .9

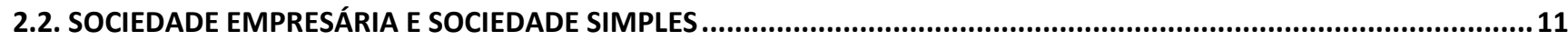

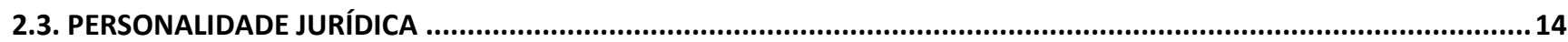

2.4. SOCIEDADES NÃO PERSONALIZADAS

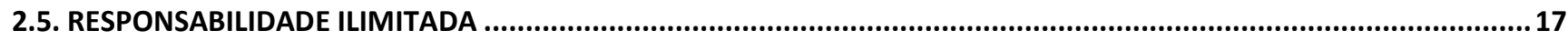

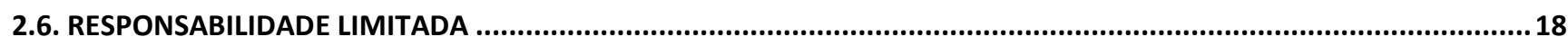

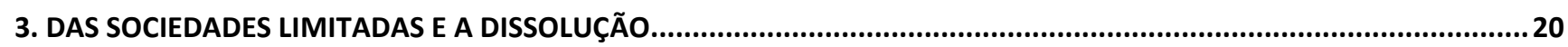

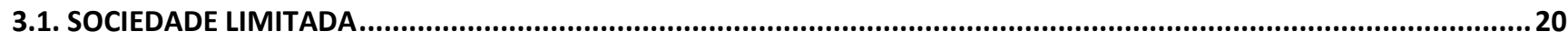

3.1.1. DO LIMITE DA RESPONSABILIDADE

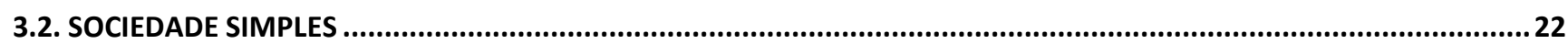

3.2.1 DO LIMITE DA RESPONSABILIDADE DOS SÓCIOS NAS SOCIEDADES SIMPLES.......................................................23

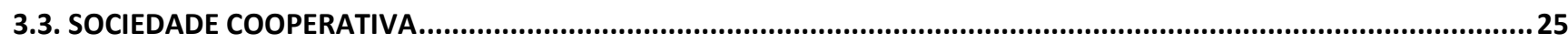

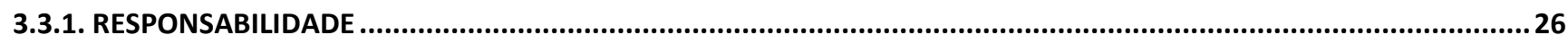

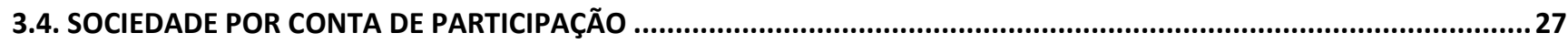

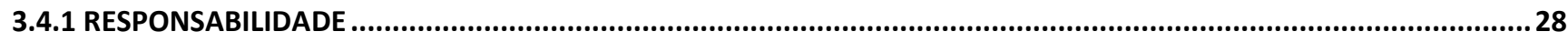

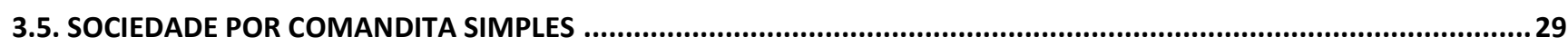

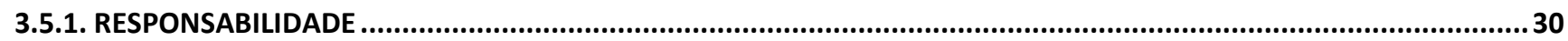

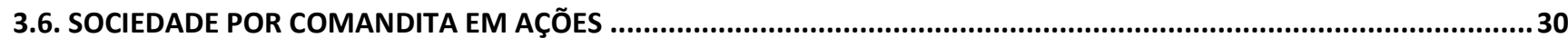

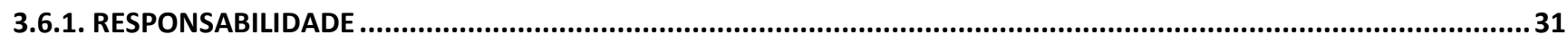

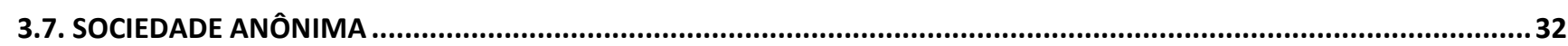

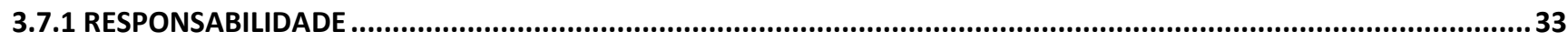

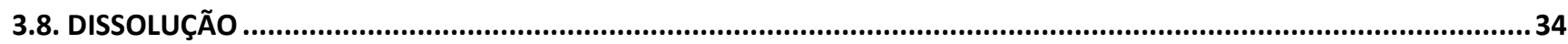

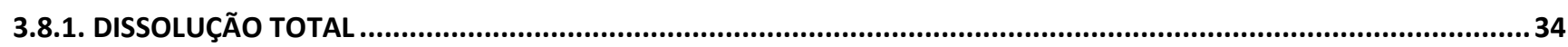

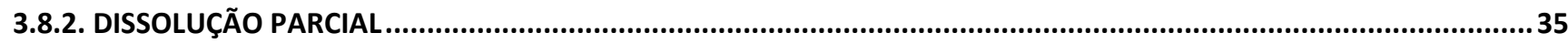

4. DA AFFECTIO SOCIETATIS E A AÇÃO DE DISSOLUÇÃo PARCIAL ….............................................................................37 


\section{Affectio Societatis Na Dissolução De Sociedade Limitada}

4.1. AÇÃO DE DISSOLUÇÃO PARCIAL.............................................................................................................................

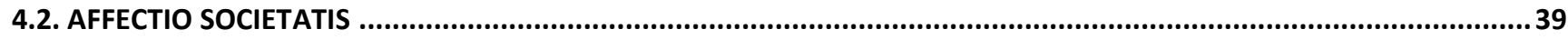

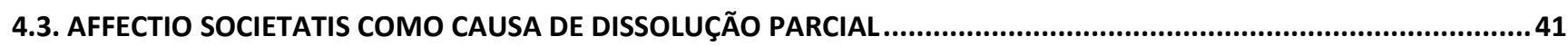

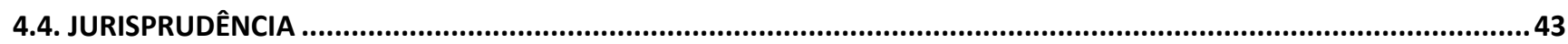

5. CONCLUSÃO 


\section{Affectio Societatis Na Dissolução De Sociedade Limitada}

\section{INTRODUÇÃO}

Atualmente vivenciamos uma fase propensa as empresas, as sociedades que as compõem, vários fatores direcionam a tamanha afirmativa como o constante desdobramento da tecnologia, a grande probabilidade de uma melhora na economia e o excessivo número de sociedades empresariais que "nascem" semanalmente, porém, talvez a fase propensa seja apenas uma grande promessa, visto que a medida que se formam sociedades empresariais, outras são dissolvidas, mas cabe observar também que dissolução não pode ser confundida com falência da empresa.

A presente pesquisa tratará sobre o tema de dissolução parcial de sociedade que passou a ter forma expressa no novo código de processo civil, especificamente no Título III, Capítulo V do NCPC. Observar também iremos a affectio societatis, cujo seu entendimento breve consiste na vontade de duas pessoas em formar uma sociedade.

Desenvolveremos ao decorrer do trabalho em razão do seu tema a seguinte problemática: O fim da affectio societatis legitima a dissolução parcial ou total de sociedade limitada?

Hipoteticamente a simples quebra da affectio societatis, que é a simples quebra da vontade dos sócios de constituir sociedade entre eles, não resulta em legitimidade para exclusão do sócio em ação de dissolução de sociedade, uma ação na qual os demais sócios tentam afastar a relação de sociedade perante o sócio que não demonstra mais vontade, excluindo-o da sociedade em questão. Já houve período no qual a configuração da perda da affectio societatis resultava na dissolução parcial com a exclusão ou retirada do sócio da sociedade em questão, porém um julgado trouxe novo e importante entendimento sobre o assunto, que não mais apenas a falta ou a violação se dá em dissolução de sociedade.

Um exemplar dessa quebra de affectio societatis é quando um sócio perde o interesse em continuar em sociedade, mas não deseja exercer seu direito de retirada, e começa a falhar com os demais sócios, com suas responsabilidades dentro da sociedade e assim prejudicando a continuidade da mesma.

O objetivo geral desta pesquisa é analisar o rompimento da affectio societatis como legitimidade em ação de dissolução total ou parcial de sociedade limitada.

A fim de alcançar o objetivo em especifico, faz-se necessário cumprir com alguns objetivos específicos, entre eles: discorrer sobre o preceito de sociedade; escrever a respeito dos tipos de sociedades limitadas existentes atualmente; enunciar as hipóteses que acarretam a dissolução parcial ou total da sociedade; e discutir sobre a affectio societatis como único fundamento para dissolução. 


\section{Affectio Societatis Na Dissolução De Sociedade Limitada}

No primeiro capítulo, necessário trazer entendimento sobre o direito societário encontrado no ordenamento jurídico, bem como características de sociedades, pressupostos, diferenças e legislação. Num segundo momento, visaremos as sociedades limitadas encontradas atualmente resguardadas por artigos legais e também causas e hipóteses em que há a possibilidade de dissolução da sociedade. No terceiro capítulo da pesquisa estuda-se exclusivamente a affectio societatis, como hipótese de criação e de dissolução de sociedade limitada, além de analise em julgado qual a menciona.

O assunto demonstra interesse, já que quem se encontra inserido em uma sociedade empresária pode se deparar com a situação na qual a sociedade passará por uma dissolução ou resolução. $O$ assunto contribui aos advogados e empresários uma vez que passam pela possibilidade de enfrentarem o caso em tela, abre assim novas perspectivas para o confronto do problema. Colabora com a sociedade o assunto de modo que melhor sejam conhecidas as causas de uma dissolução parcial, o que mantém a sociedade empresarial "viva", continuando a produzir, gerar empregos e a movimentar a economia.

Na presente pesquisa utilizamos do tipo bibliográfico, pois o tema em questão encontra-se espalhado em inúmeros meios de informação. Trata de uma pesquisa formal exploratória na qual a partir do assunto sobre dissolução de sociedade será desenvolvida a pesquisa.

A pesquisa será voltada para sociedade limitada e as hipóteses que causam a dissolução total ou parcial da mesma, fundamentado em doutrinas, artigos científicos, artigos de internet e jurisprudências.

A argumentação será sustentada em obras de autores que possuem dominância sobre o tema tratado na presente pesquisa. A técnica a ser utilizada será quantitativa onde a essência será a coleta de informações sobre o assunto.

O método de pesquisa utilizado é o dedutivo onde partiremos da premissa de sociedade para as causas de dissolução parcial ou total. Tratando-se de uma pesquisa com setor de conhecimento interdisciplinar, pois precisa da cooperação de outras disciplinas da mesma área de conhecimento como uma cooperação do Direito Comercial com o Direito Empresarial.

\section{DAS DISPOSIÇÕES GERAIS DE SOCIEDADE}

Imagine-se em uma situação na qual compõe com vossa esposa uma sociedade empresária com seu irmão e a esposa dele, com cotas $50 \%$ e 50\%, a sociedade já possui 30 anos com vários empreendimentos e clientes, um dia é citado para comparecer em juízo, pois seu irmão havia ajuizado ação de dissolução parcial para lhe excluir e excluir também vossa esposa, fundamentou a ação sobre 


\section{Affectio Societatis Na Dissolução De Sociedade Limitada}

a quebra da affectio societatis devido atritos entre os dois e trocas de calúnias, difamações e injúrias, você sabe que referidos atritos ocorreram, mas nenhum em razão da sociedade. $\mathrm{O}$ caso representado trata-se de um julgado do STJ qual será analisado em momento posterior na pesquisa.

\subsection{DIREITO SOCIETÁRIO}

No tocante a uma noção histórica sobre o direito societário Ricardo Negrão discorre onde era encontrado o tópico:

Antes da promulgação do novo Código Civil, três eram os diplomas legais que dispunham sobre as espécies societárias admitidas no Direito Comercial brasileiro: o Código Comercial de 1850, o Decreto n. 3.708, de 10 de janeiro de 1919, e a Lei n. 6.404, de 15 de dezembro de 1976. A matéria vem agora tratada nos arts. 40 a 52 e 981 a 1.141 do Código Civil de 2002, revogando expressamente os dispositivos societários constantes do Código Comercial e, tacitamente, do Decreto n. 3.708/19. (NEGRÃO, 2018, p. 193)

No período anterior ao novo Código Civil de 2002, os textos legais que continham as instruções sobre direito societário eram o Código Comercial que existia desde 1850, a lei 6.404 de 1976 e o Decreto de número 3.708 de 1919. Porém com a publicação do Código Civil de 2002 que possui em si a matéria integrada, foram revogados o Decreto 3.708 de 1919 e as partes que tratavam sobre sociedade do Código Comercial.

Sucinta é a menção de sociedades ao tocar no assunto sobre direito societário, e sobre sociedade Marlon Tomazette explana:

As atividades econômicas em geral não são desenvolvidas apenas pelas pessoas físicas isoladamente, porquanto nem sempre é possível que elas sozinhas exerçam a atividade pretendida. Em muitos casos, é necessária a combinação de esforços ou recursos dessas pessoas para que a atividade pretendida seja exercida da melhor maneira. Em outras palavras, é extremamente frequente a união dessas pessoas em sociedades para o exercício de atividades econômicas. (TOMAZETTE, 2017, p.267)

Portanto, as sociedades não são criadas por mero lazer, há uma necessidade por trás da criação de uma sociedade, como insuficiência de recursos ou capacidades que colocariam em ameaça o desenvolvimento da atividade. Pessoas então se juntam formando as sociedades, sendo que o recurso ou capacitação de uns suprem os defeitos dos outros e vice-versa, tratando de uma questão de sobrevivência no meio econômico.

O Direito Societário é voltado para a sociedade, regulando-as, impondo-Ihes limites e as tipificando como diz Tarcísio Teixeira: 
Este capítulo também poderia ser denominado apenas de "Sociedades", mas optamos por "Direito Societário" considerando a atual propagação da expressão ao se referir ao sub-ramo do Direito Empresarial que trata de sociedades, tanto da teoria geral quanto das espécies societárias. (TEIXEIRA, 2018)

Dessa forma, o Direito Societário está inserido dentro do Direito Empresarial, no qual abrange todos os tipos de sociedade, cuidando das relações entre os sócios enquanto compõem uma sociedade.

Compreende que ao falar de Direito Societário significa discorrer sobre sociedades em geral. Do mesmo modo entende André Luiz Santa na palavra:

Sucintamente, pode-se dizer que o direito societário compreende o estudo das sociedades. E as sociedades, por sua vez, são pessoas jurídicas de direito privado, decorrentes da união de pessoas, que possuem fins econômicos, ou seja, são constituídas com a finalidade de exploração de uma atividade econômica e repartição dos lucros entre seus membros. (RAMOS, 2015, p. 222)

Assim, grande parte do conhecimento sobre as sociedades encontra-se dentro do direito empresarial em sua parte que retrata o direito societário. Em respeito as sociedades, são compostas por uma pluralidade de indivíduos, que juntos almejam a mesma finalidade, o lucro, utilizando como meio para obtenção a exploração de uma atividade econômica.

Tendo em consideração a sociedade como pessoa jurídica salienta trazer os dizeres de Fábio Ulhoa Coelho:

Na construção do conceito de sociedade empresária, dois institutos jurídicos servem de alicerces. De um lado, a pessoa jurídica, de outro, a atividade empresarial. Uma primeira aproximação ao conteúdo deste conceito se faz pela ideia de pessoa jurídica empresária, ou seja, que exerce atividade econômica sob a forma de empresa. É uma ideia correta, mas incompleta ainda. Somente algumas espécies de pessoa jurídica que exploram atividade definida pelo direito como de natureza empresarial é que podem ser conceituadas como sociedades empresárias. Além disso, há pessoas jurídicas que são sempre empresárias, qualquer que seja o seu objeto. (COELHO, 2011, p.135)

Consequentemente, sociedade caracteriza-se como uma pessoa jurídica, mais especificamente uma pessoa jurídica de direito privado, já que as pessoas jurídicas de direito público são aquelas compostas por Entes Federativos, tais como União, Distrito Federal, Municípios e Estados, também os territórios e as autarquias, como descrito no Código Civil no texto do artigo 41. Além a sociedade pode ser classificada em sociedade empresária, porém apenas quando os sócios juntos buscam por uma atividade na qual o direito indica como de essência empresarial.

Logo, o Direito societário, um subproduto do Direito Empresarial, é localizado dentro do mesmo, traz em si a matéria referente às sociedades, rege e organiza os tipos de sociedades no Direito Brasileiro. 


\section{Affectio Societatis Na Dissolução De Sociedade Limitada}

Enquanto Sociedade é composta por mais de uma pessoa, por uma pluralidade de indivíduos, que em harmonia aspiram um mesmo objetivo, dando origem a uma nova pessoa jurídica de direito privado, podendo ser especificada em sociedade empresária quando sua atividade desempenhada, explorada é tida pelo direito como de natureza empresarial, havendo também sociedades que independente de seu objeto são empresárias.

\subsection{SOCIEDADE EMPRESÁRIA E SOCIEDADE SIMPLES}

Faz-se importante demonstrar o raciocínio de Luciana Pimenta:

A partir daí, podemos dizer que a sociedade empresária, como pessoa jurídica que é, pode praticar todo e qualquer ato ou negócio jurídico (lógico, desde que não exista vedação legal para tanto). Ainda que quem assine o documento seja uma pessoa física, quem se obriga, na verdade, é a sociedade. Mesmo em se tratando de Eireli, que é sociedade com um único sócio, pessoa física e pessoa jurídica não se confundem. (PIMENTA, 2015, p.68)

A sociedade como pessoa jurídica goza do direito de realizar negócio jurídico ou atos desde que não impedidos por dispositivo legal. Interessante e necessário a menção feita, ao mencionar que os sócios que compõem a pessoa jurídica quando exercem um ato ou negócio enquanto sociedade quem se obriga a aquela, é a própria sociedade. Advêm, pois, no momento em que ocorrer uma desobrigação fica responsável pela adimplência dessa a sociedade, a pessoa jurídica, ficando em cheque para cumprir com a obrigação o patrimônio da pessoa jurídica, demonstrando assim que sociedade e sócios não se misturam.

O Direito não traz de forma clara a concepção de sociedade empresária. E sobre isso Edilson Enedino fala:

Assim, nas denominadas sociedades empresárias, mesmo diante da ausência de conceito legal explícito, possível inferir do conceito legal de empresário, as características daquelas sociedades, ao tomar-se como norma de extensão o disposto no art. 966, do CC. (CHAGAS, 2017, p.156)

Então, realmente a definição de sociedade empresária não é encontrada de modo expresso dentro do regimento jurídico brasileiro, deve para tanto aplicar o artigo 966 do Código Civil, no qual refere-se à descrição de empresário singular, mas que também devido a falta do conceito legal compreende sociedade empresária.

O código Civil de 2002 traz no texto do artigo 966 a definição de empresário, porém, verifica-se que dita definição pode ser atribuída tanta a pessoa física, a um indivíduo, quanto a pessoa jurídica, uma coletividade de pessoas físicas, traz ele: 
Art. 966. Considera-se empresário quem exerce profissionalmente atividade econômica organizada para a produção ou a circulação de bens ou de serviços.

Parágrafo único. Não se considera empresário quem exerce profissão intelectual, de natureza científica, literária ou artística, ainda com o concurso de auxiliares ou colaboradores, salvo se o exercício da profissão constituir elemento de empresa (BRASIL,2002)

Tem-se sociedade empresária aquela que tem como fulcro alguma atividade econômica organizada que seja voltada para produzir ou circular bens ou serviços. Carrega o parágrafo único do dispositivo legal o que não é empresário. Conceitua o que se difere de sociedade empresária, que são as sociedades onde a atividade que exerce não é de natureza empresarial, mas de natureza literária, artística ou científica, tem o nome de sociedade simples dentro do ordenamento jurídico.

Sobre essa distinção entre sociedade empresária e simples é notório o discurso de André Luiz Santa Ramos:

Portanto, assim como nem todas as pessoas físicas que exploram atividade econômica são qualificadas como empresários individuais (cite-se: por exemplo, o profissional intelectual - art. 966, parágrafo único, do Código Civil), não são todas as sociedades que podem ser qualificadas como sociedades empresárias. Assim, as Sociedades podem ser de duas categorias: a) sociedades simples, que são aquelas que exploram atividade econômica não empresarial, como as sociedades uniprofissionais estudadas no capítulo II; b) sociedades empresárias que exploram atividade empresarial, ou seja, exercem profissionalmente atividade econômica organizada para produção ou a circulação de bens ou de serviços (art. 966 do Código Civil). (RAMOS, 2015, p. 223)

Dentro de sociedade encontra-se duas espécies a sociedade empresária e a sociedade simples. Sociedade empresária, como já dito, trata da exploração de uma atividade econômica tida de natureza empresarial que produz ou gera circulação de bens ou de serviços.

Em contrapartida as sociedades simples se desenvolvem em um ramo econômico que não possui essência das atividades consideradas empresarial.

Ainda nessa discussão das diferenciações entre as sociedades Fabio Ulhoa inclui ponto relevante sobre o lucro, diz ele:

A distinção entre sociedade simples e empresária não reside, como se poderia pensar, no intuito lucrativo. Embora seja da essência de qualquer sociedade empresária a persecução de lucros - inexiste pessoa jurídica dessa categoria com fins filantrópicos ou pios -, este é um critério insuficiente para destacá-la da sociedade simples. Isto porque também há sociedades não empresárias com escopo lucrativo, tais as sociedades de advogados, as rurais sem registro na Junta etc. (COELHO, 2011, p.136) 


\section{Affectio Societatis Na Dissolução De Sociedade Limitada}

Anteriormente, quando houve expressão em relação de lucro, correta estava, porém querer dizer que a finalidade do lucro é um fator divisor, diferenciador entre as sociedades de natureza empresarial e as de natureza intelectual é uma declaração errônea, visto que no âmbito jurídico existem as sociedades tidas como simples que exploram uma atividade visando acumular capital.

Existe diretriz necessária que ambas as sociedades devem seguir para a sua efetiva criação como Tarcísio Teixeira fala "O 'nascimento' (criação) da sociedade legalizada acontece com o registro do seu contrato social no órgão competente, o que Ihe confere personalidade jurídica (item que será tratado adiante)."(TEIXEIRA, 2018, p.151)

A sociedade legalizada apenas tem início após registrado em órgão competente seu contrato social, contrato esse plurilateral pois como já mencionado é ela composta por mais de uma pessoa, e é com o devido registro que a sociedade começa a dispor de personalidade jurídica.

Há também outras caracterizações que as sociedades, seja ela qual for, possuem em semelhança, demonstradas no discurso de Marlon Tomazette:

Acreditamos que o conceito legal não merece censura, podendo-se, pois, destacar na formulação de qualquer conceito de sociedade alguns elementos, quais sejam: (a) a existência de duas ou mais pessoas; (b) reunião de capital e trabalho (fatores da produção); (c) atividade econômica (em oposição a atividades de mero gozo, ou filantrópicas); (d) fins comuns (inerentes ao exercício da atividade por várias pessoas em conjunto); (e) partilha dos resultados (decorrência do exercício em comum). Não incluímos a personificação da sociedade, por acreditarmos que não se trata de um elemento necessário a todas as sociedades, haja vista a existência das sociedades de fato, ora chamadas sociedades em comum. (TOMAZETTE, 2017, p.268)

São esses os preceitos, os pilares que compõem as sociedades em geral como, a pluralidade de sócios, indivíduos (uma pessoa sozinha não é capaz de criar uma sociedade), o acúmulo de trabalho e recursos, a existência de uma atividade econômica a ser explorada, os indivíduos que a constituem aspiram por um mesmo objetivo, a divisão entre os sócios dos resultados e mesmo que não tenha discutido, a existência de affectio societatis entre os indivíduos, que se resume na vontade entre eles de constituírem em sociedade uns com os outros. As palavras contribuem para o entendimento que mesmo que a personificação de uma sociedade seja importante ele não é um elemento essencial para as sociedades, já que existem aquelas não têm personalidade jurídica.

Arremata-se desse modo que a origem e a legalização da sociedade resultam do registro de seu contrato social, o que traz consigo a personificação da sociedade, conferindo a ela o pleno direito de pactuar negócios jurídicos e exercer atos, na qual os atos do sócio são considerados atos da sociedade. 


\title{
Affectio Societatis Na Dissolução De Sociedade Limitada
}

No Código Civil vigente não há de forma expressa a definição de sociedade empresária, tendo de buscá-la de modo implícito no texto legal que se refere ao empresário individual, de modo a apresentar existir também a sociedade simples. É errado atribuir fins lucrativos como uma das diferenças entre elas, dando-se para distinção delas a observância do ramo econômico desempenhado por elas, a profissão intelectual, artística ou literária de natureza científica, classificam a sociedade simples a menos que o exercício constitua elemento de empresa, enquanto demais atividades organizadas que produzam ou contribuam para circulação de serviços ou bens identificam a sociedade empresária.

\subsection{PERSONALIDADE JURÍDICA}

Ricardo Negrão traz sobre a personalidade jurídica:

\begin{abstract}
A personalidade jurídica é uma fiç̧ão jurídica, cuja existência decorre da lei. É evidente que às pessoas jurídicas falta existência biológica, característica própria das pessoas naturais. Entretanto, para efeitos jurídicos e, leia-se, para facilitar a vida em sociedade, concede-se a capacidade para uma entidade puramente legal subsistir e desenvolver-se no mundo jurídico. Sua realidade, dessa forma, é social, concedendo-Ihe direitos e obrigações. (NEGRÃO, 2018, p.193-194)
\end{abstract}

Isto posto, a personalidade jurídica é uma "pessoa" fictícia que através de sua criação pode existir e se desenvolver no mundo jurídico, a qual atribui-se a uma sociedade, é ungida de capacidade meramente legal com direitos e obrigações próprias. Teixeira tece que:

\footnotetext{
A pessoa pode ser física (natural) ou jurídica. Pessoa jurídica é a entidade legalizada; um ente criado pela técnica jurídica como uma unidade orgânica e estável de pessoas para fins de natureza pública ou privada. É completamente distinta dos indivíduos que a compõem, tendo personalidade jurídica, como a pessoa física, visando obter direitos e contrair obrigações. (TEIXEIRA, 2018, p.150)
}

A personalização possui fundamento legal, podendo ser de natureza privada ou de natureza pública, também ela não pode ser confundida com os sócios que compõem como nos é exibido no artigo 49-A do Título II Das pessoas jurídicas do Código Civil de 2002 “Art. 49-A. A pessoa jurídica não se confunde com os seus sócios, associados, instituidores ou administradores."

Com o aludido dispositivo fica esclarecido que os sócios então agem através da pessoa jurídica para cumprir com os deveres e obrigações desta, onde as obrigações da pessoa jurídica não é uma obrigação do sócio, como uma obrigação de pagamento assinada por um sócio em nome da empresa, é esta última que se obriga a cumprir a obrigação. 
Da criação de uma pessoa jurídica Marlon Tomazette diz:

A doutrina não é unânime ao indicar os elementos necessários à constituição de uma pessoa jurídica, sem, contudo, chegar a divergências de maior importância. Em função disso, unindo as idéias de vários autores podemos chegar aos seguintes elementos: (a) vontade humana criadora13; (b) a finalidade específica;14 (c) o substrato representado por um conjunto de bens ou de pessoas; 15 e (d) a presença do estatuto e respectivo registro. (TOMAZETTE, 2017, p.296)

São elementos necessários para a sociedade ser personalizada, constituir em pessoa jurídica, o ânimo coletivo de criar a pessoa jurídica, na qual terá que cumprir com objetivo específico, precisando que Ihe seja composto seu patrimônio/capital, bem como as pessoas que essa representa, compor estatuto próprio e o devido registro no órgão competente. Tomazette completa o entendimento quando diz:

Ao se exercer a atividade empresarial por meio de uma pessoa jurídica, cria-se um centro autônomo de interesses em relação às pessoas que lhe deram origem, de modo que a estas não são imputados às condutas, os direitos e os deveres da pessoa jurídica. Com o nascimento dela, surge um novo centro de referência de interesses e relações jurídicas; se tem um sujeito jurídico a mais, o qual tem capacidade de direito, capacidade de querer e agir, vontade e responsabilidade patrimonial própria. (TOMAZETTE, 2017, p.296)

Quando os sócios agem através da pessoa jurídica criam em relação a eles um centro autônomo de interesse, de modo que essas ações são imputadas ao próprio centro, a pessoa jurídica, que tem plenas capacidades cíveis bem como responsabilidade patrimonial própria.

Consequentemente a sociedade busca sua personificação jurídica, procuram por compor uma pessoa jurídica através do cumprimento de uma série de atos e concebendo-a com inscrição no respectivo registro, pois ela assume as obrigações e responsabilidades das ações dos sócios em seu nome, possuindo regulamento e capital próprio, ela tem um papel de resguardar os sócios e seus patrimônios onde não são confundidos as ações da empresa com os sócios nem o patrimônio da mesma.

\subsection{SOCIEDADES NÃO PERSONALIZADAS}

Há sociedades sem personalização, nos dizeres de Maria Gabriela Venturoti Perrotta Rios Gonçalves "O novo Código Civil disciplinou dois tipos de sociedades sem personalidade jurídica: as sociedades em comum e as sociedades em conta de participação."(GONÇALVES, 2011, p.73) desse modo texto legal traz disposição que sociedade em conta de participação e sociedade em comum não possuem personalização jurídica, não podem criar uma pessoa jurídica, pois não são permitidas conceber uma. 
Registre-se que essas sociedades não personificadas, embora estejam disciplinadas na parte do Código Civil referente às sociedades empresárias, podem eventualmente desenvolver atividades civis, não empresariais. Tratase, pois, de sociedades cujo objeto social pode ser de natureza civil ou empresarial, ou seja, podem ser sociedades simples ou empresárias. (RAMOS, 2015, p. 236)

Diz que as sociedades descritas como não personalizadas, estão descritas na parte de sociedades empresariais do Código Civil, porém essas sociedades não são vinculadas exclusivamente a atividade empresária, podendo oscilar entre atividade empresarial e civil, devendo ser classificada em sociedade simples ou empresária a depender do tipo de atividade desenvolvida pela sociedade em questão.

Sobre a falta de uma personalidade jurídica acolhendo os sócios diz Elisabete Vido esclarecendo uma dúvida:

Apesar de não existir personalidade jurídica e, portanto, não haver a proteção patrimonial dos sócios, o legislador afirmou que os bens dos sócios colocados à disposição da sociedade, bem como as respectivas dívidas, constituem um patrimônio especial (art. 988 do CC). Isto significa que, apesar da ausência da personalidade jurídica, o patrimônio dos sócios não pode ser atingido diretamente e sim após esgotados os bens do patrimônio especial. (Brasil, 2002 apud. SANTOS, 2012, p.63)

Assim, a não existência de uma pessoa jurídica dotada de personalidade não quer dizer que os sócios têm seus patrimônios pessoais à disposição dos credores a qualquer momento em caso de dívida não paga. Mesmo que realmente não haja todos os benefícios e segurança que uma personalidade jurídica oferece, os sócios só respondem com seus próprios bens quando os recursos que a sociedade possui não são o bastante para satisfazer a dívida. Tomazette diz:

O direito é estabelecido para fins humanos, mas não é apenas a pessoa física que pode ser sujeito de direitos, existem outros entes que igualmente podem ser titulares de direitos e obrigações. Entre tais entes, temos as pessoas jurídicas e temos também entes despersonalizados, tendo como caráter distintivo a existência ou não de personalidade jurídica. (TOMAZETTE, 2017, p.294)

Entes personalizados e entes despersonalizados possuem plena capacidade de serem sujeitos de direitos, sendo titulares de obrigações e direitos, em que a diferença mais marcante é a existência de personalidade jurídica dos entes personalizados.

Assim, nem todas as sociedades são personalizadas, não compondo pessoa jurídica. Porém, mesmo não havendo personalização a sociedade em comum e a sociedade por conta de participação são sujeitos de direito e possuem seus próprios direitos e deveres, além de poderem essas sociedades praticar atividades cíveis. 


\subsection{RESPONSABILIDADE ILIMITADA}

Ao se tratar de sociedade importante se faz falar das responsabilidades que uma sociedade pode assumir. Marlon Tomazette traz que:

São sociedades de responsabilidade ilimitada aquelas nas quais todos os sócios respondem subsidiária e ilimitadamente pelas obrigações da sociedade, vale dizer, se o patrimônio social não for suficiente, o patrimônio de todos os sócios responde pelas obrigações da sociedade. Acreditamos que a solidariedade entre os sócios não é necessária para caracterizar tal categoria de sociedades. Dentro desta categoria estariam sempre a sociedade em nome coletivo, a sociedade em comum, as sociedades simples puras (art. 1.023) e eventualmente as sociedades cooperativas. Por razões óbvias, não se tem procurado tais tipos societários. (TOMAZETTE, 2017, p.370)

Sociedades simples pura, sociedade em comum, sociedade em nome coletivo e as cooperativas(quando em seu estatuto discriminar que a responsabilidade dos sócios é ilimitada) têm em comum a sua responsabilidade, ilimitada no caso, os sócios respondem de maneira solidária, subsidiária e ilimitada, onde o patrimônio dos sócios pode responder pelas obrigações contraídas pela sociedade.

Sobre o assunto Fabio Ulhoa explica:

Se o ativo do patrimônio social não foi suficiente para integral pagamento dos credores da sociedade, o saldo do passivo poderá ser reclamado dos sócios, em algumas sociedades, de forma ilimitada, ou seja, os credores poderão saciar seus créditos até a total satisfação, enquanto suportarem os bens dos patrimônios particulares dos sócios. (COELHO, 2011, p. 144)

Na responsabilidade ilimitada os credores conseguem saciar toda a dívida da sociedade com eles, os sócios, uma vez que os patrimônios da empresa não forem suficientes podem requerer a quitação da dívida dos próprios sócios. Ocorrem hipóteses do patrimônio dos sócios também não ser suficiente para cumprir com a obrigação com os credores, nesses casos o credor não conseguira o montante devido.

Ricardo Negrão compreende que:

Como ocorre com todas as demais pessoas físicas ou jurídicas, as empresas individuais de responsabilidade limitada (EIRELI) e as sociedades regulares respondem sempre de forma ilimitada pelas obrigações assumidas, conforme dispõe o art. 789 do Código de Processo Civil de 2015. Trata-se de responsabilidade patrimonial primária, mas os titulares da empresa e os sócios responderão ordinariamente conforme a estrutura empresarial ou social a que se submeteram, sempre subsidiariamente ao patrimônio social, (...) (NEGRÃO, 2018, p.65-66) 


\section{Affectio Societatis Na Dissolução De Sociedade Limitada}

Há sociedades em casos qual tem de responder por suas obrigações, está sempre será cobrada de forma ilimitada, possui ela uma responsabilidade patrimonial primária, sendo perseguido os sócios por trás da empresa apenas quando o patrimônio dessa não for suficiente, tendo seus titulares uma responsabilidade patrimonial subsidiária.

Pimenta, em harmonia com os demais, completa "Em algumas sociedades a responsabilidade dos sócios será ilimitada, ou seja, o banco vai tomar deles tanto quanto baste para a satisfação integral da dívida. Em outros tipos de sociedade, o banco só vai poder tomar determinado montante"(PIMENTA, 2015, p.69). Enquanto compor uma sociedade de responsabilidade ilimitada responde seus sócios além dos bens da empresa com seus próprios.

Perfaz que em questão de sociedades com responsabilidade ilimitada, seus sócios não possuem quaisquer garantias de resguardo dos próprios bens, próprios patrimônios, sendo estes bens acionados quando as posses da empresa não conseguirem cumprir com a totalidade de seus deveres e responsabilidades.

\subsection{RESPONSABILIDADE LIMITADA}

No tocante de responsabilidade limitada Marlon Tomazette esclarece:

São sociedades de responsabilidade limitada aquelas nas quais todos os sócios têm responsabilidade limitada, vale dizer, obrigam-se apenas até determinado montante, que pode ser o valor de sua contribuição ou valor do capital social. São representantes de tal categoria as sociedades anônimas e as sociedades limitadas e, eventualmente, as cooperativas. (TOMAZETTE, 2017, p.370)

Uma sociedade em que os sócios possuem responsabilidade limitada, estes respondem pelas obrigações da sociedade até a parte que Ihes cabe, seja sua cota, capital social ou valor da sua contribuição. Sociedades limitadas, sociedades anônimas e as cooperativas enquadram nas hipóteses de responsabilidade limitada, porém no tópico anterior houve afirmação que esse modelo de sociedade está na categoria de responsabilidade ilimitada, contudo nenhum está errado, tratando o próprio Código Civil de 2002 em seu artigo 1095 que as cooperativas podem assumir responsabilidade limitada ou ilimitada .

Mostra Ulhoa em um apontamento que "em outras sociedades, os credores somente poderão alcançar dos bens dos patrimônios particulares um determinado limite, além do qual o respectivo saldo será perda que deverão suportar."(COELHO, 2011, p.143) 


\section{Affectio Societatis Na Dissolução De Sociedade Limitada}

Os credores não possuem à disposição a plenitude dos patrimônios dos associados, havendo um limite até onde podem acionar os sócios para cumprir com a obrigação da sociedade em questão.

Edilson Enedino Chagas mostra a importância da limitação da responsabilidade quando:

Sem responsabilidade limitada, o pequeno empreendedor assume riscos que vão além da sua própria compreensão da responsabilidade empresarial. Formalizar-se somente compensaria caso houvesse garantia da preservação da autonomia da pessoa jurídica e respeito à responsabilidade limitada. O Estatuto Nacional da Microempresa e a legislação sobre a EIRELI e a LTDA reconhecem a necessidade de limite à responsabilidade pessoal como crucial ao exercício da atividade de produção ou circulação de bens e serviços(...) (CHAGAS, 2017, p.87)

A responsabilidade limitada é vista como crucial para o desenvolvimento e produção de atividades empresariais, pois sem ela muitos que desejarem ingressar, se tornar um empreendedor ou montar uma sociedade não prosseguiram já que arcam com tantas responsabilidades e obrigações, seriam um "freio" para não continuar a "trilhar", agora com a limitação podem sim investir e aguardar por retorno com pouco receio de perder até o que já havia conquistado.

Tomazette completa:

Em razão disso, o direito criou técnicas de limitação de responsabilidade para incentivar o desenvolvimento da própria economia, incentivando que as pessoas apliquem seus recursos em atividades econômicas produtivas, sem, contudo, correr riscos extremos de perda de seu patrimônio. Trata-se de um corolário da livre iniciativa, consoante já afirmou o STF: "um dos fundamentos do Direito de Empresa, consubstanciado na garantia constitucional da livre iniciativa, entre cujos conteúdos está a possibilidade de constituir sociedade para o exercício de atividade econômica e partilha dos resultados, em conformidade com os tipos societários disciplinados por lei, que envolve um regime de comprometimento patrimonial previamente disciplinado e que delimita o risco da atividade econômica. (TOMAZETTE, 2017, p. 91)

Com finalidade em um maior investimento nas atividades econômicas que produzem lucros e impulsionam a economia, o direito exibiu técnicas para limitar a responsabilidade patrimonial do empreendedor ou sócios, dando uma sensação de segurança, em que não seriam prejudicados por alguma futura má administração da empresa.

Deste modo a responsabilidade limitada foi inserida no âmbito empresarial com o objetivo de que mais pessoas se arriscassem, coloquem em aplicação seu capital na prosperidade da atividade econômica sem medo de algum contratempo. Aquele detentor da referida responsabilidade tem garantido a proteção de seus bens particulares, além de responder sobre as obrigações da empresa 


\section{Affectio Societatis Na Dissolução De Sociedade Limitada}

de forma subsidiára e limitada a sua cota na empresa, e apenas quando esta não consegue solver com sua obrigação.

Conclui-se que ao falar da generalidade de sociedade tem como correto afirmar que trata-se de uma pluralidade de indivíduos que têm em comum a finalidade, o desejo de exercer uma atividade em conjunto e harmonia, criar uma sociedade que a depender do objeto da atividade pode ser uma sociedade simples ou empresária, e ainda a depender do modelo societário a sociedade terá uma personalização ou não além do modelo definir o tipo de responsabilidade que os sócios possuem perante a empresa, sendo a principal diferença entre a responsabilidade limitada e responsabilidade ilimitada o limite do qual os credores podem se dispor do patrimônio particular dos titulares da pessoa jurídica.

\section{DAS SOCIEDADES LIMITADAS E A DISSOLUÇÃO}

O presente capítulo tratará de forma sucinta sobre os modelos societários, quais todos os sócios ou apenas alguns possuam uma responsabilidade limitada devido a forma adotada, ou pela possibilidade de os sócios aderirem a limitação de suas responsabilidades, abordar iremos também a temática de dissolução, bem como suas hipóteses listadas em texto legal.

\subsection{SOCIEDADE LIMITADA}

A respeito das sociedades de responsabilidade limitada a primeira a ser apresentada nesta pesquisa é o modelo societário que chamam de Sociedade limitada. Edilson Enedino fala que "a Sociedade Limitada corresponde ao tipo societário que proporciona a limitação da responsabilidade dos sócios, reduzindo o risco da atividade, razão pela qual é o mais atrativo, correspondendo a mais de $90 \%$ dos registros de sociedade do Brasil" (CHAGAS, 2017, p.239). Afirma que a maioria das sociedades compostas no Brasil são sociedades limitadas, pois esta apresenta mais benefícios que riscos aos sócios.

Maria Gabriela Venturoti Perrotta Rios Gonçalves diz:

O grande sucesso das sociedades limitadas deve-se à limitação da responsabilidade subsidiária dos sócios quanto às obrigações sociais. A limitada é a única sociedade do tipo contratual em que todos os sócios possuem responsabilidade limitada. Elas representam hoje a maior parte das sociedades empresárias existentes no país. (GONÇALVES, 2012, p.149) 


\section{Affectio Societatis Na Dissolução De Sociedade Limitada}

Estando em harmonia com Chagas confirma o sucesso da sociedade limitada devido no modelo contratual estipular uma limitação nas responsabilidades dos sócios, qual o desincumbem de uma gama de obrigações sociais.

André Luiz Santa Cruz em completa harmonia com os demais contribui:

A sociedade limitada representa, com certeza, o tipo societário mais utilizado na praxe comercial brasileira, correspondendo a aproximadamente mais de $90 \%$ dos registros de sociedade no Brasil. A grande presença de sociedades limitadas no meio empresarial se deve basicamente ao fato de ela ostentar duas características específicas que a tornam um tipo societário bastante atrativo para os pequenos e médios empreendimentos: a contratualidade e a limitação de responsabilidade dos sócios. (RAMOS, 2015, p.260)

Clara é a afirmação que o tipo societário sociedade limitada é o que possui maior espaço dentro do território brasileiro, sendo chamativo a aqueles que desejam constituir em sociedade, visto que há uma contratualidade entre as partes, que traz segurança aos sócios, reduzindo os riscos de exercer atividade econômica em sociedade, além de os sócios gozarem de responsabilidade limitada.

\subsubsection{DO LIMITE DA RESPONSABILIDADE}

Cabe mencionar os dizeres de Edilson Enedino Chagas que fala sobre a responsabilidade acerca da contratualidade "Omisso o contrato social quanto à limitação da responsabilidade, aplicava-se o regime da responsabilidade ilimitada" (CHAGAS, 2017, p.241). Logo, uma observância no contrato social da sociedade se faz útil, pois caso não estiver expresso no contrato sobre a responsabilidade limitada dos sócios, estes ficarão sujeitos a responsabilidade ilimitada.

No limite da responsabilidade deste tipo societário Maria Gabriela Venturoti Perrotta Rios Gonçalves expõe que "a responsabilidade do sócio é restrita às cotas por ele subscritas e não integralizadas, mas todos respondem solidariamente até o montante do capital total subscrito e não integralizado, tendo direito de regresso pelo que pagar por outro sócio (art. 1.052)" (GONÇALVES, 2012). Assim a sociedade limitada é constituída por cotas, cotas essas que são integradas pelos sócios que possuem responsabilidade limitada a cota que possuem e as cotas não integralizadas, diz que mesmo assim respondem de forma solidária por todo capital da sociedade integrado e não integrado.

Já Elisabete Teixeira fala que: 


\begin{abstract}
A regra geral da responsabilidade na sociedade limitada diz que cada sócio responde pela integralização do capital subscrito e, solidariamente, pelo capital não integralizado (art. 1.052 do CC). Ou seja, no exemplo acima, o sócio A responde por colocar na empresa as 70 moedas, enquanto que o sócio $B$ responde por colocar na empresa 30 moedas; além disso, no que tange as cotas não integralizadas, os sócios $A$ e $B$ respondem solidariamente até o valor do que falta integralizar, ou seja, das 20 moedas. (SANTOS, 2012, p.71)
\end{abstract}

Utilizando de um exemplo para simplificar como é a responsabilidade dos sócios na sociedade, ela mostra que cada um se obriga a sua parte subscrita seja ela totalmente integrada ou não, mas que também respondem pelas partes de outros sócios que ainda não foram integradas à sociedade.

Ricardo Negrão contribui ao dizer que:

Outros autores julgavam que todos os sócios passavam a responder solidariamente até o limite do total do capital social, independente do fato de terem integralizado sua parte, por força do art. 2 do Decreto n. 3.708/19; mas, uma vez integralizado o capital total, não mais responderiam por dívidas da sociedade. Nesse sentido as inúmeras decisões dos Tribunais: RT, 682/123170, JTACSP-RT, 97/386171; RJTJESP, 126/242172, e RT, 531/269173. (NEGRÃO, 2018, p.280-281)

Então esclarece as duas linhas de pensamento nas doutrinas, uma que diz que os sócios de uma sociedade limitada respondem de forma solidaria pelo capital total da sociedade e outra linha que julga que os sócios respondem apenas no limite que lhe cabem, Negrão ainda mostra diversas decisões de tribunais que confirmam que quando o capital total da sociedade estiver integralizado, isso é, em sua totalidade, os sócios afastam a responsabilidade de responder por dívidas da sociedade em sua totalidade, respondendo a dívida no limite de seu capital social.

Desse modo, mesmo diante de um conflito e desentendimento, é notório a explanação de Ricardo Negrão, sendo ele uma síntese entre os demais, também traz decisões de Tribunais para sustentar sua argumentação. Uma sociedade limitada possui sócios com cotas que se responsabilizam por estas, mas não apenas às suas cotas são obrigados; são eles obrigados solidariamente também pelas cotas dos demais sócios que ainda não foram inteiradas no capital total da sociedade. Numa sociedade em que há todo capital integralizado, seus sócios, que possuem responsabilidade limitada estabelecida por seu tipo societário e contrato, responderam em caso de dívida apenas ao valor das cotas que possuem.

\title{
3.2. SOCIEDADE SIMPLES
}

No tocante a sociedade simples diz Tomazette: 
Com o Código Civil de 2002, estabelecesse a dicotomia entre sociedades simples e empresárias. Em ambas há o exercício de atividades econômicas, mas as sociedades empresárias exercem atividade própria de empresário sujeito a registro e as simples não (art. 982). Assim, são sociedades simples aquelas que exercem as atividades não empresariais (nas quais a organização é menos importante que a atividade pessoal) ou atividade de empresário rural sem se registrar na junta comercial. (TOMAZETTE, 2017, p. 389)

Retorna assim ao que se diferencia uma sociedade empresária de sociedade simples, como já explanado na primeira parte da pesquisa, para determinar se uma sociedade é empresária ou simples basta uma análise no tipo de atividade econômica desenvolvida, se a atividade enquadra no parágrafo único do artigo 966 do Código Civil de 2002, que aponta quais atividades não são empresariais, e a atividade não constituir elemento de empresa, a sociedade será simples.

Quanto ao registro, Luciana Pimenta discorre que "sociedade simples é a que explora sua atividade de forma não empresarial. Seus atos constitutivos não são registrados na junta Comercial, mas sim no Cartório de Registro Civil de Pessoas jurídicas" (PIMENTA, 2015, p.87). Modo que sociedades que exploram atividade tida como empresarial, bem como as cooperativas registram-se na junta Comercial, enquanto o registro no Cartório de Registro Civil de Pessoas jurídicas fica reservado para o registro de sociedades simples.

Tarcisio lembra-nos sobre sociedade simples quando fala:

Cabe destacar que a sociedade simples tem personalidade jurídica, o que a enquadra como uma das sociedades personificadas. Em sua denominação deverá constar a expressão 'sociedade simples' ou sua abreviação ' $\mathrm{S} / \mathrm{S}$ '. Expressamente, o Código Civil não prevê a possibilidade de a sociedade simples operar por firma, apenas denominação. (TEIXEIRA, 2018, p.184-185)

Uma sociedade simples também pode compor pessoa jurídica, dotada de personalidade jurídica, sendo classificada como uma sociedade personificada, e deve levar no nome o termo $\mathrm{S} / \mathrm{S}$ ou sociedade simples como dita o próprio código civil a respeito.

Desse modo, uma sociedade simples apenas não explora alguma atividade tida como empresarial, possuindo uma própria personalidade jurídica, inscrita no Cartório de Registro Civil de Pessoas jurídicas, e leva sociedade simples no nome ou a sigla $\mathrm{S} / \mathrm{S}$.

\subsubsection{DO LIMITE DA RESPONSABILIDADE DOS SÓCIOS NAS SOCIEDADES SIMPLES}

Sobre a responsabilidade dos sócios nesse modelo societário Luciana Pimenta afirma: 
Uma sociedade simples pode adotar qualquer um dos tipos societário, exceto sociedade por ações, mas também pode não adotar nenhum tipo, e aí será considerada uma sociedade simples pura. A responsabilidade dos sócios, nesse caso, será ilimitada, mas se aplica a regra do benefício de ordem. (PIMENTA, 2015, p.87)

Então, uma sociedade simples é livre para adotar a maioria dos tipos societários existentes no ordenamento brasileiro, como também podem deixar de adotar algum se tornando uma sociedade simples pura com responsabilidade ilimitada.

Teixeira, sobre essa possibilidade de determinar o tipo societário que pode vir a ser adotado lembra:

No entanto, a sociedade simples pode assumir a forma de 'limitada', conforme prevê o art. 983 do Código Civil, o que limita a responsabilidade de seus sócios ao valor de suas respectivas quotas. Neste caso, deverá ser acrescida à sua denominação a expressão 'Itda.'. Esse fato não transforma a sociedade simples em sociedade empresária, logo, mesmo tendo os seus sócios responsabilidade limitada, ela continuará sendo registrada no Registro Civil das Pessoas Jurídicas. (TEIXEIRA, 2017, p.197, grifo do autor)

Na sociedade simples, seus sócios conseguem até fluir de responsabilidade limitada a depender do tipo adotado. Assim, aqueles que compõem a sociedade podem resguardar seus bens, porém a sociedade também levará em seu nome o que determina o tipo societário limitado, a siglas "Itda". Também aponta que uma sociedade simples não se torna empresária apenas por adotar um tipo, mas ela pode sim se tornar empresária desde que sua atividade explorada mude para alguma elencada como empresarial.

Marlon Tomazette argumenta em contrário afirmando:

Nas sociedades simples, na opinião da maioria, os sócios definem a responsabilidade, aplicando-se o artigo 1.023 do CC apenas no silêncio do contrato. A nosso ver, porém, a regra geral é o próprio artigo 1.023, que estabelece que os sócios respondem subsidiariamente, na proporção de sua participação no capital social, vale dizer, o patrimônio pessoal do sócio só responde na insuficiência do patrimônio social e pela parte da dívida equivalente à sua parte no capital social. ( TOMAZETTE, 2017, p.401)

Demonstra o entendimento que, mesmo que os sócios escolham um modelo societário eles ainda serão obrigados subsidiariamente por dívidas que excedem o patrimônio total da sociedade, podendo os sócios serem chamados para sanar a dívida existente com o próprio patrimônio.

Desse modo, quando trata de responsabilidade de uma sociedade simples, não pode já alegar se é limitada ou ilimitada, necessário é uma análise se a referida sociedade adotou algum modelo ou não; lembrando que o tipo de sociedade por ações está fora das possibilidades de escolhas. Porém, via de regra a responsabilidade de uma sociedade simples é ilimitada, e como mostra Tomazette na última 


\title{
Affectio Societatis Na Dissolução De Sociedade Limitada
}

citação os sócios por possuírem uma responsabilidade patrimonial subsidiária não conseguem se resguardar de dívidas que superem o capital da sociedade, sendo necessário que bens pessoais destes resolvam a dívida.

\subsection{SOCIEDADE COOPERATIVA}

A sociedade cooperativa é regida por lei própria, pela Lei 5.764/97 e é complementada pelo Código Civil em seus artigos 1093 ao 1096, sobre sua composição interessante ver a fala de Leonardo Gomes de Aquino:

\begin{abstract}
"Para a constituição de uma cooperativa, deve haver um número mínimo de 20 pessoas físicas que tenham um objetivo comum, ser realizada uma assembleia de constituição, elaborado um contrato (estatuto) social e o registro da documentação societária na Junta Comercial do Estado e da cooperativa, depois de constituída, nos órgãos competentes."(AQUINO, 2010, p.12)
\end{abstract}

Como em outros modelos a sua constituição está a depender de seu registro no devido órgão, através de um contrato celebrado em assembleia, o que mais nos chama atenção além da necessária assembleia de constituição é mínimo de pessoas necessárias para compor uma cooperativa devendo haver pelo menos 20 indivíduos.

Fabio Ulhoa também possui apontamento relevante:

As cooperativas, normalmente, dedicam-se às mesmas atividades dos empresários e costumam atender aos requisitos legais de caracterização destes (profissionalismo, atividade econômica organizada e produção ou circulação de bens ou serviços), mas, por expressa disposição do legislador, que data de 1971, não se submetem ao regime jurídico-empresarial. Quer dizer, não estão sujeitas à falência e não podem requerer a recuperação judicial. (COELHO, 2011, p.38)

Esse modelo societário pode então desenvolver atividades que são caracterizadas como de sociedade empresária, porém devido a lei própria que a rege, a Lei 5.764/97, não fica a cooperativa adequada ao regime de sociedade empresarial, não possuindo os direitos de falência e recuperação judicial em seu rol.

Muitos possuem suas próprias ideias do que seja uma cooperativa, sendo assim oportuno trazer as falas de quem demonstra seu ponto de vista de forma clara, e Joao Batista Brito Pereira o faz bem ao dizer: 
A cooperativa, a meu ver, é uma associação de pessoas com objetivo profissional nos diversos campos da atividade humana, administrada no modelo de autogestão, operacionalizada por meio de ajuda mutua, destinada a satisfação das necessidades básicas comuns de seus membros. É uma organização de natureza empresarial sem propósito de lucratividade, mediante a qual um grupo de pessoas busca realizar determinados interesses comuns, $\mathrm{e}$ tem o capital como instrumento a serviço do homem. (PEREIRA, 2003, p.34)

Portanto uma cooperativa é a união de pelo menos 20 membros que operam por um objetivo em comum, dispondo de lei própria para sua organização, qual mesmo desenvolvendo atividade dita como empresarial não fará parte do regime desta.

\subsubsection{RESPONSABILIDADE}

Em relação a responsabilidade dos sócios nesse modelo societário cabe trazer o texto legal do artigo 1.095 do Código Civil de 2002, traz que:

Art. 1.095. Na sociedade cooperativa, a responsabilidade dos sócios pode ser limitada ou ilimitada.

$\S 1$ o É limitada a responsabilidade na cooperativa em que o sócio responde somente pelo valor de suas quotas e pelo prejuízo verificado nas operações sociais, guardada a proporção de sua participação nas mesmas operações.

§ 2 o É ilimitada a responsabilidade na cooperativa em que o sócio responde solidária e ilimitadamente pelas obrigações sociais. (Brasil, 2002)

Mostra-nos que a cooperativa pode assumir tanto a responsabilidade limitada quanto a ilimitada, expandindo o conhecimento Tomazette diz:

Um primeiro caminho é a limitação de responsabilidade, na qual o sócio responde por sua parte no capital social, bem como pelas perdas sociais na proporção da sua participação nas referidas operações. Outro caminho é a responsabilidade ilimitada, em que o sócio responde solidária e ilimitadamente pelas obrigações sociais, independentemente da sua participação no negócio. Obviamente, se a sociedade não tiver capital social, esta última opção é a única cabível para a responsabilização dos sócios cooperados. (TOMAZETTE, 2017, p.812)

A fim de intensificar essa possibilidade de escolha da responsabilidade dos sócios, mostro a fala de Claudia Ribeiro "As principais características da sociedade cooperativa são: A responsabilidade dos sócios pode ser limitada ou ilimitada, conforme for previsto no estatuto social;" (RIBEIRO; MENEZES, 2014, p.36, grifo do autor)

Dessa forma fica firmado que ao falar sobre cooperativa falamos de um modelo societário que ao ser constituído fica em seu estatuto social definido o tipo de responsabilidade que seus sócios contraem, podendo ser limitada ou ilimitada. 


\subsection{SOCIEDADE POR CONTA DE PARTICIPAÇÃO}

A sociedade em conta de participação é outra que a ser abordarda, a iniciar pelo seu conceito que como diz Luiz Carlos Aceti Júnior:

O conceito de sociedade em conta de participação se constitui de duas ou mais pessoas, uma delas necessariamente comerciante, em nome desta girando os negócios. Conceitua Carvalho de Mendonça como "a que se forma entre pessoas, das quais uma pelo menos deve ser comerciante, para a prática de uma ou mais operações de comércio determinadas, trabalhando um, alguns ou todos os associados em seu nome individual para lucro comum" (ALMEIDA, 1997, p.19 apud. JÚNIOR, 2001, p.8)

Cumpre apresentar também os dizeres de Andre Luiz Santa Cruz sobre o modelo:

Com efeito, a exemplo do que já afirmamos quando do estudo da sociedade em comum, é incoerente chamar de sociedade a conta de participação, uma vez que ela não possui personalidade jurídica. Ademais, outras de suas especificidades, como sua natureza secreta e a ausência de nome empresarial apontam para a impropriedade técnica de se considerar a conta de participação uma espécie de sociedade. (RAMOS, 2015, p.241)

Tacisio Teixeira adiciona:

A sociedade em conta de participação é uma sociedade que só existe entre os sócios, sendo inexistente para terceiros, mas isso não impede que terceiros tomem conhecimento da sua existência, pois não é algo tido como um segredo absoluto. Mesmo assim, há quem a chame de sociedade em conta de participação de sociedade secreta. (TEIXEIRA, 2018, p.182)

Esse modelo trata de uma sociedade em comum, cujo não possui um cadastro de pessoa jurídica, acerca dos sócios existe uma peculiaridade, essa explanada por Andre Luiz Santa Cruz:

A sociedade em conta de participação apresenta duas categorias distintas de sócios: o sócio ostensivo e os sócios participantes (também chamados de sócios ocultos). A propósito, o art. 991 do Código Civil dispõe que 'na sociedade em conta de participação, a atividade constitutiva do objeto social é exercida unicamente pelo sócio ostensivo, em seu nome individual e sob sua própria e exclusiva responsabilidade, participando os demais dos resultados correspondentes'. (BRASIL, 2002 apud. RAMOS, 2015, p. 241-242)

Desenvolvendo mais a ideia das duas modalidades de sócios Arnoldo Wald contribui que:

É o que a doutrina chama de facetas interna e externa da conta de participação, a saber: ao sócio ostensivo (ou gerente) cabe exercer a atividade prevista no objeto em seu nome próprio e por sua conta e risco, enquanto que ao sócio participante (ou oculto) cabe, tão-somente, fornecer parte dos meios necessários para possibilitar a exploração do negócio - leia-se investir na 


\section{Affectio Societatis Na Dissolução De Sociedade Limitada}

atividade -, não se responsabilizando pessoalmente pelo eventual insucesso na operação. (WALD, 2016, p.2)

Com o exposto observa que, na sociedade de conta de participação existem dois tipos de sócios para seu funcionamento, o membro ativo trabalha desenvolvendo as tarefas e assumindo as consequências, enquanto o membro passivo fornece capital e participa dos lucros igualmente, este não existe em relação jurídica com terceiros, não assume riscos, ressaltando ainda que é sociedade que não possui personalidade jurídica.

\subsubsection{RESPONSABILIDADE}

Aqui a responsabilidade é diferente para os dois tipos de sócios, pois o sócio participante não está diretamente ligado aos ofícios desenvolvidos pelo sócio ostensivo que atua em nome próprio, e sobre Luciana Pimenta de maneira jocosa ao fazer uma associação dela e seu vizinho montando uma sociedade de conta de participação diz:

Dando nome aos bois, eu sou a sócia ostensiva e meu vizinho é o sócio participante. Ele só tem responsabilidade com relação a mim, da forma como estipulado no contrato (limitada ou ilimitadamente), e não tem qualquer tipo de relação com meus credores. Somente eu quem exerço o objeto social, por minha conta e risco. (PIMENTA, 2015, p.85)

Já se mostra mais evidente a diferença de responsabilidade que cada um assume, Gladston Mamede intensifica sobre a responsabilidade do sócio ativo ao dizer: "O sócio em posição ostensiva se apresenta em nome próprio, como pessoa que atua individualmente e que assume, pessoal e exclusivamente, a responsabilidade decorrente da atividade."(MAMEDE, 2010, p.20). Enquanto o sócio passivo, menciona Fabio Martins de Andrade que:

Salvo esta situação específica, o sócio participante participa geralmente com o capital e participa dos resultados do negócio (ganhos e perdas). A responsabilidade do sócio participante limita-se aos estritos termos descritos no contrato social firmado entre ele e o sócio ostensivo. A relação de direitos e obrigações prevista no contrato social é exclusiva entre ambos, sem qualquer eficácia perante terceiros. Assim, em princípio, o sócio participante não tem nenhuma responsabilidade societária. (ANDRADE, 2008, p.4)

Aponta assim que nesta sociedade o sócio ostensivo nunca irá responder de forma limitada pelos seus atos, pois não existe uma pessoa jurídica que o resguarde e é nele que recai todos os danos e perdas, além dos deveres provenientes, sempre atuando com responsabilidade ilimitada, em contrapartida o participante tem a sua definida no contrato da sociedade assinado entre eles. 


\subsection{SOCIEDADE POR COMANDITA SIMPLES}

Nesse tópico Edinilson Enedino das Chaga já deixa um aviso a respeito "As Sociedades em Nome Coletivo, em Comandita Simples, em Comandita por Ações constituem-se em tipos societários formalmente possíveis, mas dificilmente utilizáveis, cujas normas jurídicas correspondentes se encontram em desuso." (CHAGAS, 2017, p.187). São poucos os que optam por estes tipos provavelmente por haverem outros mais vantajosos.

Esse modelo cujo iremos tratar possui similaridade com o anterior, traz Tarcisio Teixeira uma análise da palavra comandita "Comandita significa administrada ou comandada. É um termo derivado do italiano accomandita, cujo significado era guarda ou depósito, uma vez que no passado pessoas confiavam seu capital a outrem para que este o administrasse em seu nome e risco." (TEIXEIRA, 2018, p.200, grifo do autor). Vemos a existência de dois tipos de sócios nas falas de Gladston Mamede que menciona também o que é comandita:

Entre tais posições, corretas estão as últimas; comanditar e fornecer fundos para uma atividade negociai, simples ou empresária, que será gerida por terceiros, que gerem, não comanditam. São os sócios comanditários que comanditam; são eles o sujeito ativo necessário do verbo, criado para traduzir o ato que praticam: entregar valores a custodia de outrem, formando os fundos para a sua existência e funcionamento da sociedade: comanditar, $\mathrm{O}$ sujeito passivo da ação de comanditar e o comanditado, aquele que recebe os valores em custodia e a quem cabe guarda-lo e protege-lo (tuere, em latim, traduz-se por ter debaixo da vista, protegei; manter),6 ou seja, a quem cabe ocupar-se do negócio, concretiza-lo por meio de atos cotidianos. (MAMEDE, 2010, p.300)

Tarcisio Teixeira ainda tece que:

A sociedade em comandita simples é aquela em que há sócios com responsabilidade limitada e sócios com responsabilidade ilimitada e solidária. Essa sociedade possui personalidade jurídica e pertence ao quadro das sociedades personificadas. A expressão "simples" vale para diferenciá-la da sociedade em comandita por ações, a qual é uma espécie de sociedade anônima, que estudaremos adiante. (TEIXEIRA, 2018, p.199)

Evidente fica a existência de uma personalidade jurídica, além de haver também os comanditários que participam com capital e dos comanditados que administram, Monica Gusmão fala um pouco acerca do contrato social:

O contrato social tem de discriminar os comanditados e os comanditários. Essas sociedades regem-se pelo Capitulo III do Código Civil.12 Onde couber, aplicamse as comanditas simples as normas das sociedades em nome coletivo (em relação aos sócios comanditados) e das sociedades simples. (GUSMÃO, 2009, p.181) 


\section{Affectio Societatis Na Dissolução De Sociedade Limitada}

Assim mesmo que pouco utilizado possui respaldo em lei, nos artigos 1.045 ao 1.051 do Código Civil sendo mais objetivo, há dois sócios que não se misturam cada um com sua responsabilidade com será apresentado.

\subsubsection{RESPONSABILIDADE}

Mencionado já foi que há os colaboradores que respondem limitadamente e os que respondem ilimitadamente, sobre Monica Gusmão diz:

"Diz-se sociedade em comandita simples, a formada por duas espécies de s6cios, os comanditados, pessoas físicas, com responsabilidade ilimitada, e os comanditários, pessoas físicas ou jurídicas. obrigados somente pelo valor de suas quotas, e com responsabilidade limitada." (GUSMÃO, 2009, p.180)

De forma direta já delimita as responsabilidades de cada, da mesma forma faz Ricardo Negrão ao falar dos tipos de sócios "Sócios comanditários, obrigados somente pelo valor de sua cota, e sócios comanditados, responsáveis solidária e ilimitadamente pelas obrigações sociais, de forma subsidiária ao patrimônio social (art. 1.045)." (BRASIL, 2002 apud. NEGRÃO, 2018, p.277).

Eles têm foco no assunto sendo diretos nessa diferenciação de responsabilidades, Fabio Ulhoa integra:

É o tipo societário em que um ou alguns dos sócios, denominados 'comanditados', têm responsabilidade ilimitada pelas obrigações sociais, e outros, os sócios 'comanditários', respondem limitadamente por essas obrigações. Somente os sócios comanditados podem ser administradores, e o nome empresarial da sociedade só poderá valer-se de seus nomes civis, portanto. Ademais, devem ser necessariamente pessoas físicas. Disciplinam a sociedade em comandita simples os arts. 1.045 a 1.051 do CC. (COELHO, 2011, p.176)

Após o exposto é certo que aquele que gerencia os recursos da sociedade, trabalha com o terceiro, delega funções é o comanditado que responde ilimitadamente e solidariamente por seus atos, não sendo necessariamente apenas um, e há o sócio comanditário que fornece recursos e responde no limite de suas cotas, onde não pode gerenciar correndo risco de responder de maneira ilimitada e solidaria com os outros comanditados se o fazer.

\subsection{SOCIEDADE POR COMANDITA EM AÇÕES}

O modelo de sociedade por comandita em ações assim como as demais está devidamente regulamentada no código civil, porém não apenas ele a rege, descreve o artigo 1090 do código civil que "Art. 1.090. A sociedade em comandita por ações tem o capital dividido em ações, regendo-se pelas normas relativas à sociedade anônima, sem prejuízo das modificações constantes deste Capítulo, 


\section{Affectio Societatis Na Dissolução De Sociedade Limitada}

e opera sob firma ou denominação." (BRASIL, 2002). Estando disciplinada também na LSA (Lei da sociedade anônima).

No tocante ao nome aqui nesse tipo de sociedade Ricardo Negrão (2018) explica que é possível usar de firma ou denominação, ambos contendo em seguida comandita por ações ou a abreviação dessa, em firma pode conter nome ou nomes apenas dos acionistas cujo são diretores.

André Luiz Santa Cruz Ramos sobre os diretores aponta:

De acordo com o art. 1.091, § 2..$^{\circ}$, do Código (regra que é idêntica à do art. 282, $\S 1.0$, da LSA) 'os diretores serão nomeados no ato constitutivo da sociedade sem limitação de tempo, e somente poderão ser destituídos por deliberação de acionistas que representem no mínimo dois terços do capital social'. E a legislação ainda se preocupou em estabelecer as "responsabilidades dos acionistas diretores após o término dos seus respectivos mandatos. Nesse sentido determina o art. 1.091, $\S 3 .^{\circ}$, do Código (regra que, por sua vez, é semelhante à do art. $282, \S 2 .^{\circ}$, da LSA) que 'o diretor destituído ou exonerado continua, durante dois anos, responsável pelas obrigações sociais contraídas sob sua administração'. (BRASIL, 2002 apud. RAMOS, 2015, p.377)

O diretor ou diretores são apontados na criação, e são eles que gerenciam, administram a sociedade, a opinião deles deve ser levada em consideração, principalmente em algumas questões como expõe Luciana Pimenta (2015) que há temas que dependem da posição do(s) diretor(es) como alteração do objeto social, extensão de prazo, mudança no capital social da sociedade, sobre criação de debênture(espécie de título de credito) e abertura para novos beneficiários.

Pelo observado encontra-se nesse modelo também dois tipos de sócios um passivo, e um ativo, acionista e diretor respectivamente, delimitados na criação da sociedade, cabe ao diretor a gerência e as obrigações sociais, sendo possível responsabilizar pelas obrigações sociais feitas durante o mandato o diretor que foi exonerado ou destituído do cargo pelo período de até dois anos após deixar o cargo.

\subsubsection{RESPONSABILIDADE}

No quesito da responsabilidade é direto Edilson Enedino das Chagas (2017), trabalha ele de forma clara e objetiva as responsabilidades dos sócios dos tipos existentes em um quadro qual no modelo que trabalhamos existe uma dualidade de responsabilidade qual a dos acionistas diretores(administradores) é solidária e ilimitada e o meramente acionistas respondem limitadamente. 
Fabio Ulhoa Coelho (2011) firma sobre, diz ele que o diretor responde de forma ilimitada pelas obrigações contraídas pela sociedade, e por isso só acionistas podem ocupar a diretoria, sendo eles nomeados no estatuto, sem prazo determinado, com a possibilidade de serem removidos do cargos, por vontade dos acionistas cujo a soma das ações deem pelo menos dois terços do capital da sociedade.

Theotonio Negro traz o texto do artigo 1.091 do código civil de 2002:

Art. 1.091. Somente o acionista tem qualidade para administrar a sociedade e, como diretor, responde subsidiária e ilimitadamente pelas obrigações da sociedade.1 [Sem dispositivo correspondente no CC/1916.]

$\S 1$ o Se houver mais de um diretor, serão solidariamente responsáveis, 2 depois de esgotados os bens sociais. (BRASIL, 2002 apud. NEGRAO; GOUVEA; BONDIOLI; FONSECA, 2018, p.812)

Acompanha também a mesma linha Tarcisio Teixeira (2018) explica que apenas quem faz parte do quadro de acionistas pode desempenhar o cargo de administrador, qual nessa situação responde da maneira ilimitada e subsidiaria, desta forma deixamos frisado a responsabilidade que pendura na sociedade em comandita por ações.

\subsection{SOCIEDADE ANÔNIMA}

Resta apresentar a sociedade anônima qual Maria gabriela Ventuoti Perrot(2012) esclarece que possuem outro nome sendo chamadas também de companhia, disciplinadas em lei própria a lei da sociedade anônima (LSA), Lei no 6.404/76 e em omissão desta o código civil de 2002 age como complemento.

Os sócios são acionistas, donos de ações dentro da sociedade, e são estas que formam o capital social da sociedade como traz Joaquín Garrigues:

O capital se mede pelas subscrições feitas pelos sócios, e as contribuições em dinheiro, ou em bens suscetíveis de avaliação em dinheiro, hão de chegar ao nível das ações subscritas. Depois de feitas as contribuições para o capital, há que defender o capital fornecido, porque este é não só o capital de exploração com que conta a sociedade, mas também a única garantia dos credores,[...] Esta defesa do capital se consegue proibindo-se que a sociedade restitua aos sócios suas contribuições e regulando coercitivamente as diminuições de capital decididas pela assembleia geral, de modo que não implique uma fraude para os credores. Aos acionistas se thes pede unicamente seu dinheiro, não seu trabalho, porque para conseguir os fins sociais há outras pessoas que podem, sem dúvida, ser também acionistas, mas que não precisam sê-lo, porque a sociedade anônima funciona sob o princípio do "organicismo de terceiros", alheios à corporação; ao contrário do que ocorre na sociedade coletiva, na qual 


\section{Affectio Societatis Na Dissolução De Sociedade Limitada}

os próprios sócios são os órgãos administradores da sociedade. (GARRIGUES, 2002, p.2)

O capital composto pelas ações é a única linha de garantia dos credores, tanto que é vedado restituir a contribuição do sócio, mesmo com a morte dele, abre assim a possibilidade que com a morte de algum acionista essa sua característica possa ser sucedida por seus herdeiros legais como diz Marlon Tomazette:

Com efeito, a sociedade anônima é uma típica sociedade de capitais, haja vista a maior importância atribuída à contribuição do sócio e não às suas qualidades pessoais. Em função disso, é livre a negociação de ações, que pode ser eventualmente restringida (art. 36 da Lei 6.404/76), mas nunca impedida,10 pois não importam as qualidades pessoais dos sócios, mas sua contribuição patrimonial. Outrossim, o falecimento dos sócios não terá quaisquer consequências sobre a sociedade, transmitindo-se de pleno direito a condição de sócio aos seus herdeiros. (BORBA, 1998 apud. TOMAZETTE, 2017, p.513)

Dessa maneira a lei que a rege elucida tudo ao respeito do modelo, bem como suas características, como há de ser feita sua denominação, avaliação dos bens, responsabilidade dos sócios e trata de diversos outros temas acerca de da S.A (sociedade anônima).

\subsubsection{RESPONSABILIDADE}

No artigo primeiro da lei própria (Lei 6.404/76) já se encontra a responsabilidade do sócio “Art. 10 A companhia ou sociedade anônima terá o capital dividido em ações, e a responsabilidade dos sócios ou acionistas será limitada ao preço de emissão das ações subscritas ou adquiridas."

Tem eles uma responsabilidade limitada ao valor de suas ações, Fabio Ulhoa Coelho (2010) complementa que eles possuem uma obrigação no limite do valor total de sua ação não apenas a que esteja fazendo parte do capital da sociedade, mas também a parte que falta para a integralização da mesma.

Sobre essa obrigação da ação em sua totalidade explana Edilson Enedino das Chagas que:

Tal como a sociedade de responsabilidade limitada, na companhia a responsabilidade dos sócios também é limitada. Mas a limitação da responsabilidade é diferente nestas duas espécies de sociedades. Na sociedade limitada, os sócios respondem pela integralização das quotas que subscreveram e são solidariamente responsáveis pela integralização total do capital social (exegese do art. 1.052, do CC). Desse modo, enquanto o capital social não estiver totalmente integralizado, ou seja, pago, a responsabilidade dos sócios é solidária e limitada, embora subsidiária. Os acionistas das companhias, por seu turno, respondem apenas pelo valor de emissão das ações que subscreveram, não havendo se falar em responsabilidade solidária quanto à integralização de todo o capital social. (CHAGAS, 2017, p.275) 


\section{Affectio Societatis Na Dissolução De Sociedade Limitada}

Dessa forma não há de se falar em solidariedade entre os sócios pelo capital da sociedade não integrado, resta agora uma dúvida acerca da responsabilidade do acionista administrador, e a respeito explica Fábia Duarte Ferreira(2018) que as ações praticadas pelo acionista administrador são de responsabilidade da sociedade, pois eles atuam como um órgão da sociedade, porém podem eles responder civilmente por danos causados dolosamente ou culposamente se agirem de forma oposta ao disposto em lei ou ao estatuto social da S.A.

Atribuímos dessa forma a responsabilidade limitada ao presente modelo societário, qual cada sócio é obrigado a própria ação subscrita seja ela plenamente parte do capital da sociedade ou não, mesmo os administradores aqui gozam de limitação da responsabilidade desde que ajam em harmonia com o estatuto da sociedade e com lei. Trataremos a diante hipóteses que acarretam dissolução dos modelos anteriormente retratados.

\subsection{DISSOLUÇÃO}

A dissolução de uma sociedade está devidamente constada no Código Civil em artigos próprios, a dissolução é o encerramento da sociedade, o fim de sua atividade, seu "desmanche" em outras palavras, porém em interseção desse conceito há o princípio da preservação da empresa, Fabio Ulhoa(2011) explica sobre esse princípio, que os sócios devem resolver seus assuntos particulares, suas faltas sem que prejudiquem a empresa e sua atividade econômica. Da proteção desse princípio nascem duas formas de dissolução de sociedade, a total e a parcial.

\subsubsection{DISSOLUÇÃO TOTAL}

Na forma total ocorre como elucidado anteriormente, o fim da sociedade por completo previsto no código civil de 2015 em seu artigo 1033, taxa ele as hipóteses em que a dissolução total será o resultado, traz que:

Art. 1033. Dissolve-se a sociedade quando ocorrer:

I - o vencimento do prazo de duração, salvo se, vencido este e sem oposição de sócio, não entrar a sociedade em liquidação, caso em que se prorrogará por tempo indeterminado;

II - o consenso unânime dos sócios;

III - a deliberação dos sócios, por maioria absoluta, na sociedade de prazo indeterminado;

IV - a falta de pluralidade de sócios, não reconstituída no prazo de cento e oitenta dias;

V - a extinção, na forma da lei, de autorização para funcionar. 


\begin{abstract}
Parágrafo único. Não se aplica o disposto no inciso IV caso o sócio remanescente, inclusive na hipótese de concentração de todas as cotas da sociedade sob sua titularidade, requeira, no Registro Público de Empresas Mercantis, a transformação do registro da sociedade para empresário individual ou para empresa individual de responsabilidade limitada, observado, no que couber, o disposto nos arts. 1.113 a 1.115 deste Código. (Redação dada pela Lei no 12.441, de 2011) (BRASIL, 2002)
\end{abstract}

Um artigo claro, direto e taxativo, qual cumprindo com algum dos requisitos dar-se a dissolução, salvo nas hipóteses nele mesmo expressas. Tarcisio Teixeira(2018) ainda fala que há outras formas de ocorrer a dissolução, como pelo contrato social da sociedade que pode prever outras clausulas de dissolução, um exemplo usado por ele é uma clausula que prevê a dissolução em caso de falecimento, morte de qualquer dos sócios, e a outra forma é uma dissolução judicial, o sócio faz o requerimento judicial para anular o contrato que compõe a sociedade, ou é requerido quando da sociedade não resta mais finalidade social.

Complementando as outras hipóteses em que enseja dissolução Andre Luiz Santa Cruz Ramos lembra que "Não se deve esquecer ainda o caso da falência da sociedade, que também acarreta a sua dissolução" (RAMOS, 2015, p.393) lembrando do processo de falência que após desenvolvido também há a dissolução da sociedade em questão.

Assim a dissolução total falha com o princípio de preservação da empresa, pois nele há o encerramento completo das atividades, e acaba o vínculo entre todos os sócios pertencentes a ela, evidente ainda que suas causas não se encontram exclusivamente em seu artigo legal, ocorrendo em outras hipóteses judiciais forenses como em falência ou a pedido de sócio, ou em hipóteses extrajudiciais como em hipóteses diversas no próprio contrato da sociedade.

\title{
3.8.2. DISSOLUÇÃO PARCIAL
}

Na dissolução parcial não ocorre o mesmo que na total como é de se esperar, não há encerramento da empresa, a empresa é mantida "viva", existe e é respeitado o princípio da preservação da empresa, o que e dissolvido é o vínculo entre sócio e sociedade, o tema é maior reconhecido em doutrina e normas como "resolução da sociedade em relação a um sócio", conforme confirma Tarcisio Teixeira "A dissolução parcial no capítulo sobre as sociedades simples é chamada de 'resolução da sociedade em relação a um sócio'. Resolução tem o sentido de rescisão, no caso, a rescisão da sociedade com relação a um de seus sócios, seja pela sua exclusão, morte etc." (TEIXEIRA, 2018, p.164, grifo do autor).

De maneira a apoiar e esclarecer a escolha dessa denominação traz Roberta de Oliveira: 


\begin{abstract}
A expressão "dissolução parcial" para indicar a situação em que há afastamento de um ou alguns sócios sem a extinção da sociedade, sempre foi ferozmente criticada pela doutrina, não obstante seja hoje bastante costumeira. A crítica nasce da impropriedade de que não se trata de dissolução da sociedade, mas de um rompimento unilateral de um sócio em relação ao contrato social. Seria, portanto, mais acertada a expressão resolução, rescisão ou resilição(...) (OLIVEIRA; RIBAS, 2015, p.7)
\end{abstract}

Até os dias de hoje ao falarmos de dissolução parcial, entende-se a informação de resolução da sociedade perante um ou mais sócios, tanto que a todo tempo remetem o assunto ao termo utilizado, Fabio Ulhoa também o faz nos dizeres:

A dissolução parcial da sociedade (isto é, a "resolução da sociedade em relação a um sócio") pode ser provocada, na maioria das vezes, por: $a$ ) vontade dos sócios; $b$ ) morte de sócio; $c$ ) retirada de sócio; $d$ ) exclusão de sócio; $e$ ) falência de sócio; $f$ ) liquidação da quota a pedido de credor de sócio. (COELHO, 2015, p.205)

Ainda traz de modo organizado e agrupado as hipóteses que tendem a preceder a dissolução do vínculo com o sócio, situações essas de comum compreensão e entendimento, comentadas a seguir de modo breve e objetivo, para início a vontade dos sócios, Gladson Mamede(2010) explica que esta ocorrera pela deliberação da maioria dos sócios, a maioria da sociedade escolhera por resolver o vínculo com outro sócio.

A morte do sócio é causa clara e objetiva, André Luís Santa Cruz Ramos diz, "Portanto, conforme o disposto no Código Civil, a sociedade contratual não se dissolverá em caso de morte de um dos sócios. O máximo que pode ocorrer é a dissolução parcial da sociedade, com a consequente apuração de haveres do sócio falecido." (RAMOS, 2015, p.400) é estabelecido um teto de consequência para a morte do sócio, porque André Luís Santa Cruz (2015) esclarece que é possível que os herdeiros assumam a cota do pai falecido nos casos que no contrato da sociedade haja clausula expressa.

Enquanto em sociedade os sócios também possuem a possibilidade de se desvincularem dela, tem eles o direito de retirada, sobre apresenta o Código Civil em seu artigo 1029 que:

Art. 1.029. Além dos casos previstos na lei ou no contrato, qualquer sócio pode retirar-se da sociedade; se de prazo indeterminado, mediante notificação aos demais sócios, com antecedência mínima de sessenta dias; se de prazo determinado, provando judicialmente justa causa.

Parágrafo único. Nos trinta dias subsequentes à notificação, podem os demais sócios optar pela dissolução da sociedade. (BRASIL, 2002)

Dessa forma o sócio pode exercer esse direito a qualquer momento desde que avise aos demais sócios com determinada antecedência, assim podem decidir por dissolver completamente a sociedade ou buscar outro sócio para ocupar o lugar de retirante. A exclusão de um sócio pode ocorrer de duas 


\section{Affectio Societatis Na Dissolução De Sociedade Limitada}

maneiras, explica Edilson Enedino das Chaga(2017) que se sucede em caso de sócio remisso, que não cumpriu com sua obrigação de integralizar sua quota social, e em caso de exclusão por justa causa, qual o sócio apresenta grande e inegável risco para empresa devido suas ações ou omissões, logo estes podem vir a ser excluídos da sociedade pelos demais em reunião marcada, qual os sócios a serem excluídos podem ir e apresentar argumentos defesa.

Sobre sócio falido e liquidação da cota a pedido de credor Roberta de Oliveira se apoiando no código civil fala que:

Tem-se no parágrafo único, do artigo 1.030, do Código Civil de 2002, que a exclusão de um sócio dar-se-á de pleno direito nos casos em que seja declarado falido ou sua quota tenha sido liquidada nos termos do parágrafo único, do artigo 1.026. Este, por sua vez, determina que, se a sociedade não estiver dissolvida, pode o credor requerer a liquidação da quota do devedor, cujo valor, apurado na forma do artigo 1.031 (que determina liquide-se o valor da quota com base na situação patrimonial da sociedade), será depositado em dinheiro, no juízo da execução, até noventa dias após aquela liquidação. (BRASIL, 2002 apud. OLIVEIRA; RIBAS, 2015, p.17)

Será devidamente resolvida a sociedade perante o sócio que é falido ou o que for devedor e seu credor a requerer pretendendo reaver seu credito, onde o valor que o sócio dissolvido receberia irá direto a juízo de execução. Passamos pelos motivos que geram a resolução da sociedade em relação a um ou mais sócios, todos presente de forma dispersada no texto legal do Código Civil.

Desta forma após apresentar os modelos societários que resguardam seus sócios com uma responsabilidade limitada, além de demonstrar a respeito da dissolução, bem como suas formas e hipóteses encerramos o presente capitulo que cumpriu com seu objetivo com a presente pesquisa, tornando possível o desdobramento do próximo capitulo qual será exibido a ação de dissolução e haverá a discussão acerca do affectio societatis junto de analises jurisprudenciais selecionadas sobre assunto.

\section{DA AFFECTIO SOCIETATIS E A AÇÃO DE DISSOLUÇÃO PARCIAL}

Neste terceiro e final capitulo da pesquisa iremos elucidar as etapas de uma resolução de sociedade perante um ou mais sócios, observando aumentar a afinidade com o próximo tópico que será apresentado após que é a affectio societatis, e ela como uma das hipóteses que geram dissolução parcial, ao fim o que apresentamos será solidificado por analises jurisprudenciais para mais credibilidade no capitulo. 


\subsection{AÇÃO DE DISSOLUÇÃO PARCIAL}

A ação de dissolução parcial possui procedimentos mais simples que na ação de dissolução total, pode deduzir que é devido tratar de remover sócio do quadro societário de uma sociedade e não encerrar por completo as atividades de uma sociedade.

Graciela I. Marins disso fala que "Quando for parcial, o autor estará requerendo a sua retirada da sociedade ou a exclusão de outro sócio e a consequente apuração dos seus haveres. Ou seja, a sociedade continuará existindo, em plena atividade, mas com a saída de sócio." (MARINS, 2004, p. 3) há legitimidade para propor a ação o próprio sócio que deseja sair da sociedade exercendo seu direito de retirada e a sociedade que anseia pela exclusão de algum ou alguns sócios, após o pedido e dado procedimento por parte do juiz ocorrerá a apuração de haveres.

Tarcísio Teixeira (2018) harmoniza em suas falas onde explica a dualidade da dissolução e que na parcial há uma liquidação nas quotas sociais para que seja pago ao sócio ou a herdeiro de direito um valor proporcional as suas quotas. Ainda em dissolução parcial de sociedade Daniel Amorim citando o novo código de processo civil sobre a ação diz:

Referida ação poderá ter dois pedidos formulados isoladamente ou em cumulação, conforme previsão do art. 599 do Novo CPC: (I) a resolução da sociedade empresária contratual ou simples em relação ao sócio falecido, excluído ou que exerceu o direito de retirada ou recesso; (II) a apuração dos haveres do sócio falecido, excluído ou que exerceu o direito de retirada ou recesso; ou (III) somente a resolução ou a apuração de haveres. (BRASIL, 2002 apud. NEVES, 2016, p.1810)

Traz os pedidos que podem na ação ser arguidos, acolhendo o juiz a ação e ao dar procedência na mesma há início da parte qual ocorre a apuração de haveres, Flavio Quinaud Pedron diz:

Sendo decretada a dissolução parcial por sentença, o procedimento segue para a fase de apuração de haveres. Aqui, seu escopo primordial é definir o quantum a ser pago ao sócio que se retira da sociedade. 0 art. 604 afirma que: 'Art. 604. Para apuração dos haveres, o juiz: I fixará a data da resolução da sociedade; II definirá o critério de apuração dos haveres à vista do disposto no contrato social; e III nomeará o perito.' (BRASIL, 2002 apud. PEDRON; CAZASSA, 2017, p.9)

Com o acolhimento da resolução dar-se-á início a fase da apuração, onde de acordo como o NCPC será estabelecida data, nomeado um perito para a resolução e observará o contrato social para saber como será efetuada a apuração, ocorre que há casos em que não há estabelecido no contrato a maneira qual se fara a apuração e sobre Humberto Theodoro Junior com amparo no NCPC fala "De acordo com o NCPC, 'em caso de omissão do contrato social' será utilizado o balanço patrimonial, para cálculo dos 


\section{Affectio Societatis Na Dissolução De Sociedade Limitada}

haveres (art. 606, primeira parte). Privilegia-se, dessa forma, o critério que os próprios sócios escolheram e registraram no contrato social." (THEODORO, 2016, p.311) Explica que nestes casos já existe previsão legal para a ação cabível no caso que é usar a balança patrimonial para apurar os haveres.

Deste modo a ação de dissolução parcial em seu procedimento inicia como qualquer outra ação pela sua proposição por parte legitima para pleiteá-la, onde com a análise e procedência do pedido por parte do Juiz, há a apuração dos haveres do(s) sócio(s) em questão, pois serão reembolsados pela sociedade com um montante proporcional a liquidação de sua quota e então a resolução do vínculo com a sociedade.

\subsection{AFFECTIO SOCIETATIS}

O termo affectio societatis já apresentado de maneira breve e rápida será agora trago com maior desenvolvimento e de começo faz necessário as palavras de Jonathas Lima Soler qual traz um contexto histórico simples, porém muito informativo:

O conceito trazido pelo Direito Romano não foi incorporado expressamente pela nossa legislação. Em 1850, o Código Comercial Brasileiro (Lei 556/1850) não apontava a affectio societatis como elemento constitutivo da sociedade.10 Da mesma forma, o Código Civil de 1916 (Lei 3.071/1916) e o Código Civil de 2002 (Lei 10.406/2002) também não contém esta norma. Trata-se, portanto, de construção doutrinária e jurisprudencial. (SOLER, 2015, p.3)

O termo assim como o Direito foi primeiramente apresentado pelos romanos, mas como aponta nem em 1850, 1916 e em 2002 no Código Civil apareceu o conceito expresso, alegando ser a jurisprudência e doutrinas que o consolidaram. Álvaro Rodrigues Junior(2003) comenta também sobre a ausência de previsão expressa do conceito como característica para sociedade não apenas no texto legal do Brasil como também nos países que utilizam do sistema de common law, além de Portugal, Argentina, Espanha, Alemanha, Itália, França e México.

Mesmo Diante da não previsão do conceito, doutrinas e jurisprudências o abordam e Edilson Enedino das Chagas relaciona o conceito a artigo do Código Civil quando fala:

A affectio socíetatis, correspondente ao elemento psicológico a aproximar os empreendedores, pode ser contextualizada na confiança mútua e na expectativa de reciprocidade relacionada à comunhão de esforços e na partilha dos resultados, condicionantes que expressamente se leem no art. 981, do CC (CHAGAS, 2017, p.172) 


\section{Affectio Societatis Na Dissolução De Sociedade Limitada}

Para ele ao fazer uma contextualização de seu conceito de affectio societatis possível se torna o encontro dele em lei legal, no próprio Código Civil, acontece que sobre o conceito há bastante divergência, Gladson Mamede apresenta uma tradução literal de affectio societatis diz ele:

Affectio soeietatis seria, traduzindo in verbis, uma afeição societária ou afeição para a sociedade; afeição não por sua tradução emocional, por certo, embora se encontre tal interpretação hermenêutica, conduzindo a análise dos problemas societários para os tormentosos sítios dos sentimentos e dos conflitos sentimentais. Melhor e compreender a afeição societária como animus contrahendae societatis, ou seja, intenção ou animo de contratar e manter uma sociedade, o que somente em alguns pontos específicos conduz o debate para os sentimentos vividos pelos sócios quotistas ou acionistas, como se vera. (MAMEDE, 2010, p.113-114)

Extrai-se importante informação da fala, affectio societatis também pode ser encontrado entre doutrinas e jurisprudências tratado como animus contrahendi societatis, uma vontade de contrair sociedade. Ricardo Negrão (2018) traduz affectio societatis como uma intenção de união, qual os sócios se unem e mantem uma participação ativa na sociedade a fim de um mesmo objetivo, sendo elemento essencial em sociedade de pessoas, mas menos importante na sociedade de capital.

Elisabete Teixeira Vido dos Santos (2012) comentando sobre as características gerais das sociedades empresárias fala sobre a affectio, que tem presença na sociedade de pessoas, sendo um vínculo de confiança e colaboração entre os sócios para atingir o fim social da sociedade, qual esse elemento é o que dá razão aos sócios de negarem entrada na sociedade de um terceiro estranho.

Esse elemento é visto por muitos como essencial para existir sociedade, Luciana Pimenta sobre constituição de sociedade contratuais diz que:

Cabe mencionar ainda mais um requisito, não de validade, mas de existência do contrato social. É a chamada affectio societatis, que nada mais é que a vontade dos sócios de se unir para a formação de uma empresa. Fácil visualizar que o requisito é de existência, né? Se não houver essa intenção, o contrato nunca vai existir. (PIMENTA, 2015, p.77)

Sem todos os elementos não há contrato e sem contrato não há uma sociedade, ainda sobre affectio societatis não podemos deixar fora os dizeres de Fabio Ulhoa Coelho, que no assunto seus pensamentos nos clarificam:

Cabe fazer menção, ainda, aos pressupostos fáticos da existência de qualquer sociedade empresária, que são dois: a affectio societatis e a pluralidade de sócios. O primeiro diz respeito à disposição, que toda pessoa manifesta ao ingressar em uma sociedade empresária, de lucrar ou suportar prejuízo em decorrência do negócio comum. Esta disposição, este ânimo, é pressuposto de fato da existência da sociedade, posto que, sem ela, não haverá a própria 


\section{Affectio Societatis Na Dissolução De Sociedade Limitada}

conjugação de esforços indispensável à criação e desenvolvimento do ente coletivo. (COELHO, 2011, p.159-160)

Trata com tamanha essencialidade o conceito que para ele é um dos pressupostos qual deve ser observado de forma antecipada para que fale em criar sociedade empresária. Então de fato há divergências na interpretação do conceito de affectio societatis, ou animus contrahendi societatis como é possível encontrar em debates, porém não são descomunais como pensávamos.

Torna-se possível após vermos diversos pontos de vista diferentes chegar a interpretação do conceito de affectio societatis simples e direto que é traduzido por ser uma vontade entre os sócios de contrair sociedade entre si, cooperando entre sí para alcançar o objeto social da sociedade. Como um pressuposto para criar uma sociedade, qual a consequência caso esse se encerre enquanto já em sociedade? É o que será apresentado a seguir.

\subsection{AFFECTIO SOCIETATIS COMO CAUSA DE DISSOLUÇÃO PARCIAL}

A resposta para a pergunta anteriormente indagada pode ser respondida já em primeiro momento pelas palavras de Edilson Enedino das Chaga que diz a respeito "A affectio societatis compõe pressuposto não só da constituição, mas igualmente da permanência do empreendimento comum, tendo em vista que seu esmaecimento superveniente poderá ser causa para a dissolução total ou parcial da sociedade." (CHAGAS, 2017, p.172) É então consequência caso a affectio societatis se encerre em quanto sociedade a dissolução da mesma.

Flávio Quinaud Pedron (2017) traduz que a devida importância do elemento se dá pelo motivo de haver tribunais que acatam a possibilidade de dissolução parcial em casos em que há o rompimento desse. Motivos como morte, exclusão ou retirada do sócio são causas de dissolução parcial da sociedade, e em exclusão para que possam os demais sócios excluir outro deve essa ser por causa justa, sobre Humberto Theodoro Junior fala:

Prevendo o art. 1.034, II, que a sociedade pode ser dissolvida quando 'exaurido o fim social, ou verificada a sua inexequibilidade', desenvolveu-se a tese de que a sociedade poderia dissolver-se parcialmente para excluir o sócio que tivesse quebrado a affectio societatis, confundindo-se tal quebra ora com a discórdia entre os sócios, ora com o descumprimento dos deveres que impede o preenchimento do fim social. (BRASIL, 2002 apud. THEODORO, 2016, p.302303)

Fabio Ulhoa desdobrando o artigo 1.034, II do CC traz maiores elucidações sobre a inexequibilidade: 


\begin{abstract}
A inexequibilidade do objeto social vem descrita como causa dissolutória pelo art. 1.034, II, in fine, do CC. Pode ser causa de dissolução judicial ou extrajudicial, consoante já visto. São exemplos de inexequibilidade do objeto social: $a$ ) inexistência de mercado para o produto ou serviço fornecido pela sociedade (falta de interesse dos consumidores); $b$ ) insuficiência do capital social para produzir ou circular o bem ou serviço referido como objeto no contrato social; $c$ ) a grave desinteligência entre os sócios, que impossibilite a continuidade de negócios comuns. (COELHO, 2011, p.204)
\end{abstract}

Ao falar a respeito do exemplo c), atrito entre os sócios qual prejudica o prosseguimento dos negócios é estar falando de quebra da affectio societatis, afirmação possível através de uma interseção com o pensamento de Humberto Theodoro. Armando Rovai(2017) salienta que os Juízes apenas apreciavam pedidos de dissolução parcial pela quebra da confiança quando estes vinham de sociedades pessoais, mas que atualmente houve evolução positiva do assunto, observando os elementos e hibridismo das sociedades limitadas, sendo admito hoje dissolução parcial de sociedades anônimas fechadas de "intuitu personae".

Andre luiz Santa Cruz Ramos(2015) argumenta a respeito do apaziguamento do Superior Tribunal de Justiça sobre a dissolução parcial da sociedade anônima, concluíram que nas que possuam claro vinculo intuitu personae, de affectio societatis e um claro rompimento posterior do vínculo há espaço para dissolução parcial, a fim de preservar a empresa.

Daniel Amorim Assumpção Neves sobre o Superior Tribunal de Justiça traz "Segundo o Superior Tribunal de Justiça, o simples rompimento da affectio societatis como causa de exclusão de sócio, por ser ato de extrema gravidade, exige não apenas sua alegação, mas a demonstração de uma justa causa, (..)" (NEVES, 2016, p.1816-1817).

Importante trazer as falas de Monica Gusmão sobre as alegações de perda de affectio societatis em ações de dissolução:

Diante de conceitos tão subjetivos, caberá ao Judiciário valorar a justa causa imputada como fundamento do pedido de exclusão do sócio, ainda que contratualmente previsto. $O$ sócio não pode ser excluído da sociedade de forma arbitrária, ou por capricho. Não basta para a exclusão mera alegação de quebra da affectio societatis, sem prova dos requisitos do art. 1.085 do Código Civil. 0 sócio acusado de modo leviano pode opor-se, como é curial, à deliberação que o excluiu, e pleitear sua anulação e subsequente reingresso na sociedade, com o ressarcimento de eventuais prejuízos sofridos, notadamente os morais. (GUSMÃO, 2009, p.279)

Forma que apenas trazer em juízo alegação de rompimento da affectio societatis não acarretará em dissolução parcial, sendo necessário para tal fatos e argumentos que devidamente a demonstre, podendo sócio injustamente dissolvido reclamar em juízo anulação e para que seja reingressado a 


\section{Affectio Societatis Na Dissolução De Sociedade Limitada}

sociedade com merecida indenização por prejuízos. Portanto o elemento essencial para constituir sociedade é também uma hipótese de sua dissolução, sendo necessário além de sua arguição as provas apropriadas que a justifique como verdadeira aos magistrados que apreciam a matéria, entendimento pelo Superior Tribunal de Justiça já pacificado. Será trago adiante jurisprudências com o escopo de testemunhar no mundo jurídico o que foi exposto e apresentado.

\subsection{JURISPRUDÊNCIA}

No que fala a respeito da jurisprudência, existe recurso especial supramencionado no início, trata-se do REsp no 1.129.222- PR, qual envolve uma sociedade composta de quatro sócios, dois irmãos e suas esposas, cada um dos casais detém $50 \%$ da sociedade, a peça inicial foi interposta com o intuito de excluir o outro irmão e a esposa dele, sob a alegação de rompimento da affectio societatis, eis a ementa do referido recurso especial:

CIVIL E COMERCIAL. RECURSO ESPECIAL. DISSOLUÇÃO PARCIAL DESOCIEDADE. EXCLUSÃO DE SÓCIO. QUEBRA DA AFFECTIO SOCIETATIS.INSUFICIÊNCIA. 1. A ausência de decisão sobre o dispositivo legal supostamente violado, não obstante a interposição de embargos de declaração, impede o conhecimento do recurso especial. Incidência da Súmula211/STJ. 2. O reexame de fatos e provas em recurso especial é inadmissível. 3. Deficiência de fundamentação do recurso. Incidência da Súmula284/STF. 4. Inexiste ofensa ao art. 535 do CPC, quando o tribunal de origem pronuncia-se de forma clara e precisa sobre a questão posta nos autos. 5. Para exclusão judicial de sócio, não basta a alegação de quebrada affectio societatis, mas a demonstração de justa causa, ou seja, dos motivos que ocasionaram essa quebra. 6 . Recurso especial a que se nega provimento. (STJ, 2011)

Recurso qual foi negado provimento por unanimidade, devido inúmeros motivos, e dentre eles o argumento que a mera alegação de quebra da affectio societatis não tem força suficiente para amparar a exclusão judicial de sócio, e acrescentamos as falas da relatora Ministra Nancy Andrighi:

Em suma, várias são hipóteses que autorizam a dissolução parcial de uma sociedade, por meio da exclusão de um ou mais sócios. Elas podem ser legais, contratuais ou decorrentes de inadimplemento do dever de colaboração social (affectio societatis), sendo imprescindível, nesse último caso, que haja a comprovação desse inadimplemento, com a especificação dos atos que foram praticados pelo sócio que se pretende excluir, os quais estariam a prejudicar a consecução do fim social da empresa. Em outras palavras, que fique caracterizada a justa causa para a exclusão. (STJ, 2011)

A Ministra deixa bem claro e evidenciado que é fator importante demonstrar fatos que comprovem o rompimento entre os sócios, fatos esses seriam trazer provas de má gerência, demonstrar atos irregulares, desleixo, negligência, enfim praticas que acabam por colocar o prosseguimento da sociedade em risco. 


\section{Affectio Societatis Na Dissolução De Sociedade Limitada}

Outra jurisprudência, ação em que um dos sócios da sociedade por cotas, pleiteia pela dissolução da sociedade sob a alegação de ruptura, o autor trouxe a juízo fatos que a caracterizassem e foi dado provimento a seu pedido, a outra parte inconformada propôs apelação ao juízo de 20 instância, a apelação cível no 1.0433.08.249786-1/001 da comarca de Montes Claros que acompanha a seguinte ementa:

DISSOLUÇÃO DE SOCIEDADE - QUEBRA DA AFFECTIO SOCIETATIS CARACTERIZADA - DECISÃO MANTIDA. Evidenciada a quebra da affectio societatis, mostra-se adequada a dissolução da sociedade por cotas de responsabilidade limitada. (TJ-MG, 2010)

O apelante por sua vez no mérito negou as provas dos autos, alegando ser sempre confiável e fiel, nunca falhando com seus deveres, diferente do que apresentava as provas, porém a decisão do juiz "a quo" foi mantida, a relatora Selma Marques em seu voto no tocante as falas do apelante traz o seguinte:

Se é certo que o réu defende-se das acusações do autor, afirmando que não faltou com os seus deveres de lealdade e em momento algum negligenciou o cumprimento de suas obrigações, nem utilizou indevidamente o seu poder de gêrencia, não menos certo é que imputa ao autor também condutas impróprias a condução da sociedade, no entanto, esta troca de insinuações só vem a reforçar a inconteste quebra da affectio societatis, outra alternativa não restando senão a de decretar a dissolução da sociedade, conforme bem decidiu o MM. Juiz a quo. (TJ-MG, 2010)

A relatora nota ressentimentos e desapreço entre os sócios e essa troca de acusações apenas evidenciava mais a ruptura, além que já havia também observado nos autos que ambas as partes estavam em harmonia sobre dissolver a sociedade, fazendo-a levar em consideração também o inciso XX do artigo 5o da Constituição Federal de 1988 que traz que ninguém é forçado a permanecer associado, sendo sensata em manter a decisão de 10 instância.

Uma jurisprudência mais atual, uma sociedade por cotas de responsabilidade limitada formada por dois sócios, um oferece ação com pedido de dissolução de sociedade com exclusão do sócio minoritário sob a alegação de quebra da affectio, pedido provido pelo juiz "a quo", descontente a outra parte interpôs apelação e o juiz de segunda instância sob argumento que não há prova de justa causa para sua exclusão, o douto juiz "ad quem" deu causa a ré, reformando a sentença proferida em primeira instância, a parte inicialmente autora teve negado o provimento de recurso especial, interpondo em seguinte um Agravo interno no recurso especial que segue a seguinte ementa:

AGRAVO INTERNO NO RECURSO ESPECIAL. APLICAÇÃO DO DIREITO INTERTEMPORAL. ENUNCIADO ADMINISTRATIVO N. 2/STJ. DISSOLUÇÃO PARCIAL DE SOCIEDADE CUMULADA COM PEDIDO DE EXCLUSÃO JUDICIAL DE 
SÓCIO MINORITÁRIO. ALEGAÇÃO DE QUEBRA DA AFFECTIO SOCIETATIS. INSUFICIÊNCIA. PRECEDENTES. DIVERGÊNCIA JURISPRUDENCIAL. AUSÊNCIA DE COTEJO ANALÍTICO. NÃO DEMONSTRAÇÃO. AGRAVO IMPROVIDO. 1. Na hipótese em exame, aplica-se o Enunciado 2 do Plenário do STJ: "Aos recursos interpostos com fundamento no $\mathrm{CPC} / 1973$ (relativos a decisões publicadas até 17 de março de 2016) devem ser exigidos os requisitos de admissibilidade na forma nele prevista, com as interpretações dadas, até então, pela jurisprudência do Superior Tribunal de Justiça." 2. Cinge-se a controvérsia acerca da possibilidade de o sócio majoritário pleitear a dissolução parcial de sociedade por cotas de responsabilidade limitada, formada por dois sócios, com a expulsão judicial do sócio minoritário do seu quadro societário, sob a escusa de quebra da affectio societatis, quando não há especificação nem demonstração na petição inicial de eventual prática de justa causa por parte do sócio cuja exclusão se pretende. 3. A jurisprudência do Superior Tribunal de Justiça já se pronunciou sobre a questão, firmando entendimento no sentido de que: "Para exclusão judicial de sócio, não basta a alegação de quebra da affectio societatis, mas a demonstração de justa causa, ou seja, dos motivos que ocasionaram essa quebra." (REsp 1.129.222/PR, Rel. Ministra NANCY ANDRIGHI, TERCEIRA TURMA, julgado em 28/06/2011, DJe de 10/08/2011) 4. $\mathrm{Na}$ hipótese, o Tribunal de origem, em consonância com o entendimento firmado nesta Corte Superior, reformou a sentença exarada pelo Juízo singular, para julgar improcedente o pedido inicial, sob o fundamento de que as autoras buscam a dissolução parcial de sociedade empresária com a exclusão da sóciaré, com base no singelo argumento de quebra da affectio societatis, ou seja, sem, contudo, alegarem causa específica que justificasse a exclusão da ré do quadro societário da segunda autora, o que desautoriza o acolhimento da pretensão inicial, visto que, para se pretender excluir sócio do quadro social de sociedade por cotas de responsabilidade limitada, faz-se necessária a prova da justa causa, o que não houve no caso dos autos. 5. Destarte, uma vez que o v. acórdão recorrido, ao resolver a controvérsia atinente ao pedido de expulsão judicial de sócio minoritário do quadro social de sociedade por cotas de responsabilidade limitada, adotou a orientação firmada pela jurisprudência desta Corte Superior, não há que falar em ofensa aos artigos 1.030 e 1.085 do Código Civil, tampouco em reforma do aresto hostilizado, que deve ser mantido por seus próprios fundamentos. 6 . Para a correta demonstração da divergência jurisprudencial, deve haver o cotejo analítico com exposição das circunstâncias que identificam ou assemelham os casos confrontados, a fim de demonstrar a similitude fática entre os acórdãos impugnado e paradigma, bem como a existência de soluções jurídicas díspares, nos termos dos arts. 541, parágrafo único, do CPC e 255 , § 2을 do RISTJ, o que não houve no caso dos autos. 7. Agravo interno a que se nega provimento. (STJ, 2018)

A agravante a fundamenta na ofensa aos artigos 1.030 e 1.085 do Código Civil, ofensa ao artigo 5으, XX da CF/88 e que existe divergência jurisprudencial, desejando que a sentença de primeira instância seja mantida. O douto relator em seu voto utiliza de diversas jurisprudência para deixar nítido os entendimentos da corte, bem como cita a REsp no 1.129.222- PR para mostrar a necessidade de justa causa para motivo de exclusão de sócio, sobre as ofensas aduziu que o acordão recorrido utilizou orientação de jurisprudência do Superior Tribunal de Justiça, não se falando mais em ofensa, e a respeito de divergência de jurisprudência declara que para sua definição não basta meras transcrições 


\section{Affectio Societatis Na Dissolução De Sociedade Limitada}

de ementas e trechos de votos sem a exposição e identificação das razões que tornam os casos semelhantes, por fim foi o agravo interno negado.

Para terminação mais uma jurisprudência, uma sociedade anônima de capital fechado composta por irmãos qual irmão mais novo oferece ação para retirar-se da sociedade, para ser excluído do quadro societário, para tanto afirma quebra de affectio societatis, seu foi dado procedência sendo sentenciado a dissolução com sua retirada e a devida apuração de haveres, a sociedade então apresentou apelação cível, eis sua ementa:

AÇÃO DE DISSOLUÇÃO DE SOCIEDADE. CERCEAMENTO DE DEFESA NÃO VERIFICADO. QUEBRA DA AFFECTIO SOCIETATIS. COMPROVAÇÃO. DISSOLUÇÃO DEFERIDA. MANUTENÇÃO. Constatando-se que a prova testemunhal indeferida pelo Juízo não irá elucidar nenhuma questão relevante para o deslinde da demanda, não cabe falar em cerceamento de defesa. A quebra da "affectio societatis" dispensa a prova pretendida pela recorrente, vez que o simples fato de o recorrido pretender se retirar da sociedade já corrobora tal ocorrência, não podendo ele ser constrangido a permanecer na sociedade. Havendo elementos suficientes nos autos que demonstrem conflitos e desarmonia entre os sócios, ocasionando a instabilidade dos seus interesses, é de se reconhecer a quebra da "afecctio societatis" e a conseqüente dissolução da sociedade. (TJMG, 2019)

Em matéria preliminar alegaram que houve cerceamento de defesa uma vez que o juiz de primeira instância dispensou a produção de prova oral e em matéria de mérito pediram a reforma para que o apelado ora autor da peça inicial não fosse excluído do quadro da sociedade, fundando que o mesmo estava desejando se "safar" dos resultados de sua má administração, incompetência, irresponsabilidade. $\mathrm{O}$ digno relator em seu voto, na sede preliminar apresenta o artigo $130 \mathrm{CPC}$, diz ser o juiz o condizente da direção do processo bem como o destinatário das provas, pode o juiz de ofício indeferir as diligências que julgar inúteis ou protelatórias, e por se tratar de sociedade de irmão de nada contribuiria a produção de prova oral, rejeitando a preliminar. No mérito declara que no caso a retirada não se faz necessário a demonstração da justa causa da quebra, pois há resguardo de seu direito de retirada no artigo 1029 do CPC qual em sociedade de tempo indeterminado para exercer direito de retirada deve avisar os sócios com antecedência de 60 dias e no artigo 5ㅇ, XX da CF/88 qual ninguém fica obrigado a se associar ou permanecer associado, assim negando o provimento da apelação.

As jurisprudências expostas apresentam lapso temporal entre elas, feito com intuito, a fim de observar como tempo afetaria, ou mudaria como são julgadas as lides, o que não ocorreu, os tribunais acerca 


\section{Affectio Societatis Na Dissolução De Sociedade Limitada}

do tema continuam a falar a mesma "língua", havendo já entendimento firmado no Superior Tribunal de Justiça.

\section{CONCLUSÃO}

Observamos que o Direito empresarial disciplina sobre o direito societário, que uma sociedade apenas é possível com a junção de indivíduos que almejam um mesmo objetivo, qual ao formarem uma sociedade as ações destes e obrigações contraídas serão recebidas como da sociedade em si, podem ser simples ou empresárias dependendo da atividade a ser desempenhada e os sócios gozam de responsabilidade ilimitada ou limitada estabelecida pelo modelo social adotado ou no contrato social. Nota-se também que existe a possibilidade de encerrar a sociedade seja de forma total ou parcial, a diferença entre os dois tipos e que na parcial há continuidade das atividades, sendo rompido os laços de um ou uns sócios com a sociedade, motivada por iniciativa dos demais ou do próprio sócio.

O desenvolvimento da presente pesquisa afirmou e comprovou dados ao decorrer de seu avanço como a affectio societatis que traduz em aspiração em associar, confiança e lealdade entre os sócios qual é característica imprescindível para formar sociedades limitadas, e também qualidade que causa seu desfazimento, havendo inúmeros processos de dissolução que apoiam-se na argumentação de rompimento da affectio societatis.

Mencionado em ênfase em ações que possuem o escopo de excluir sócio ou sócios do quadro societário da sociedade em questão, porém não é assim tão descomplicado, a exclusão de sócios que gera em primeiro momento a dissolução e em segundo a liquidação da parte devida a sócio é vista como ato extremista e de último caso, onde a singela alegação de quebra de affectio societatis não possui a robustez necessária para provimento do pedido, importante é a demonstração de fatos que comprovem a justa causa da exclusão, a exemplo trazer que os atos do sócio tornaram-se duvidosos, atua com irresponsabilidade e pratica má-administração, de modo que sua continuidade na sociedade carrega consequências para continuação da mesma, impedindo-a de alcançar seu fim social.

Há a utilização do argumento também para exercer direito de retirada da sociedade, ocorre que não existe a obrigação de trazer e apontar a justa causa no caso de sociedade por tempo ilimitado, tem o referido direito proteção pela própria Constituição Federal de 1988, mais específico em seu artigo 5으, inciso XX qual não obriga ninguém a associar ou a manter uma associação, além de haver também previsão no artigo 1.029 CC que traz o único requisito para exercer esse direito que é avisar 


\section{Affectio Societatis Na Dissolução De Sociedade Limitada}

previamente os outros sócios (no caso de sociedade por tempo indeterminado, na de tempo determinado faz preciso a justa causa).

Pela investigação dos aspectos analisados o objetivo geral da presente pesquisa significou em alcançado, visto que foram os objetivos específicos cumpridos, visto as disposições que cercam a sociedade, os modelos cujo há responsabilidade limitada envolvida, apreciado as hipóteses que promovem a dissolução, e a exibição e discussão da declaração de quebra da affectio societatis como causa de dissolução.

A temática abordada ainda resta muito espaço para eventuais pesquisas e estudos, como no segundo momento da dissolução que há a liquidação e apuração de haveres, trazendo as consequências nessa em caso de sócio qual cometeu atos de improbidade administrativa através de desvio de recursos da sociedade para si.

Percebe-se que o exposto contribui a atualidade, traz informações que agregam a matéria de sociedades e também a dissolução, sendo de maior interesse a operadores e agentes do Direito, também a aqueles inseridos hoje em algum dos tipos de sociedade presente, além para todo e qualquer indivíduo que aspira por mais conhecimento.

Por fim resta afirmar que a hipótese inicialmente proposta resta em verdadeira, pois a simples quebra da confiança entre os sócios não é justo motivo para excluir o outro, sendo inescusável para tanto trazer a juízo causas clara da impossibilidade de continuação da sociedade caso não haja a procedência do pedido, entendimento concreto da Corte Superior sendo considerado marco desse entendimento o julgamento do recurso especial no 1.129.222- PR arbitrado pela Ministra Nancy Andrighi e é até hoje usado como precedente para esclarecer que o pedido carece de justa causa, para que seja devidamente caracterizado o rompimento da affectio societatis. 


\section{BIBLIOGRAFIA}

ANDRADE, F. M. D. DA SOCIEDADE EM CONTA DE PARTICIPAÇÃO. Revista dos Tribunais Online, vol.33, p.39-56, Jan - Mar. 2008.

AQUINO, L. G. D. AS FORMALIDADES NA CONSTITUIÇÃO DAS SOCIEDADES ESTATUTÁRIAS. Revista dos Tribunais Online, vol.50, p.91-112, Out. 2010.

BRASIL. LEI № 6.404, DE 15 DE DEZEMBRO DE 1976. Dispõe sobre as Sociedades por Ações., 15 dez. 1976.

. LEI № 10.406, DE 10 DE JANEIRO DE 2002. Institui o Código Civil., 10 jan 2002.

Superior Tribunal de Justiça (T3 - TERCEIRA TURMA) . RECURSO ESPECIAL: REsp 1.129.222 PR (2009/0051257-8). Recorrente: Seme Raad e outro. Recorrido: Faissal Assad Raad e outro. Relator: Ministra Nancy Andrighi. Paraná, 28 de junho de 2011. Jusbrasil, 01 agosto 2011. Disponivel em: $<$ https://stj.jusbrasil.com.br/jurisprudencia/21104145/recurso-especial-resp-1129222-pr-20090051257-8-stj/inteiro-teor-21104146>.

Superior Tribunal de Justiça (T4 - QUARTA TURMA). AGRAVO INTERNO NO RECURSO ESPECIAL : AgInt no REsp 1479860 RJ (2014/0066204-5). Agravante: Edilene Cândido da Silva. Agravado: Raquel Maria de Oliveira Torres. Relator: Ministro Lázaro Guimarães (DESEMBARGADOR CONVOCADO DO TRF 5a REGIÃO). Rio de Janeiro, 20 de setembro de 2018. Jusbrasil, 26 setembro 2018. Disponivel em: <https://stj.jusbrasil.com.br/jurisprudencia/860231012/agravo-interno-no-recurso-especial-agintno-resp-1479860-rj-2014-0066204-5/inteiro-teor-860231032>.

Tribunal de Justiça de Minas Gerais (Câmaras Cíveis Isoladas. 11a CÂMARA CíVEL). Apelação Cível no 10433082497861001 Montes Claros. Apelante: Ivan Ferreira de Jesus. Apelado: Edmundo Aleixo Vieira. Relator: Selma Marques. Montes Claros, 14 de janeiro de 2010. Jusbrasil, 01 março 2010. Disponivel em: <https://tj-mg.jusbrasil.com.br/jurisprudencia/939677551/apelacao-civel-ac10433082497861001-montes-claros/inteiro-teor-939677671>.

Tribunal de Justiça de Minas Gerais (13a CÂMARA CíVEL). Apelação Cível no 10000180877714001 MG. Apelante: Transegura Corretora de Seguros Ltda. Apelado: Rafael Otaviano Meira. Relator: Alberto Henrique. Belo Horizonte, 14 de fevereiro de 2019. Jusbrasil, 15 fevereiro 2019. Disponivel em: <https://tj-mg.jusbrasil.com.br/jurisprudencia/932438167/apelacao-civel-ac10000180877714001-mg/inteiro-teor-932438180>.

CHAGAS, E. E. D. Direito Empresarial Esquematizado. São Paulo: Saraiva, 2017.

COELHO, F. U. Manual de direito comercial: direito de empresa. São Paulo: Saraiva, 2011.

GARRIGUES, J. A SOCIEDADE ANÔNIMA E OS ACIONISTAS. Revista de Direito Bancário e do Mercado de Capitais, vol. 15, p. 26 -280, Jan. - Mar. 2002.

GONÇALVES, M.; GONÇALVES, V. Direito comercial: direito de empresa e sociedades empresárias. São Paulo: Saraiva, 2012.

GUSMÃO, M. LIÇÕES DE DIREITO EMPRESARIAL. 8. ed. Rio de Janeiro: Editora Lumen Juris, 2009. 


\section{Affectio Societatis Na Dissolução De Sociedade Limitada}

JUNIOR, Á. R. ANÁLISE DOS CONCEITOS DE AFFECTIO SOCIETATIS E DE LIGABILIDADCOMO ELEMENTOS DE CARACTERIZAÇÃO DAS SOCIEDADES COMERCIAIS. Revista dos Tribunal Online, vol.14, p. 87-110, Abr- Jun. 2003.

JÚNIOR, L. C. A.; REIS, M. F. C. SOCIEDADE EM CONTA DE PARTICIPAÇÃO. Revista dos Tribunais Online, vol.794, p. 727-745, Dez. 2001.

MAMEDE, G. Direito Empresarial Brasileiro Direito Societario: Sociedades Simples e Empresarias Vol.2. São Paulo: Atlas S.A, 2010.

MARINS, G. I. AÇÃO DE DISSOLUÇÃO DE SOCIEDADE LIMITADA. Revista dos Tribunais, vol.116, p. 85 96, Jul-Ago. 2004.

NEGRÃO, R. Curso de direito comercial e de empresa, v. 1: teoria geral da empresa e direito societário. São Paulo: Saraiva, 2018.

NEGRÃO, T. et al. Código Civil e legislação civil em vigor. 36. ed. São Paulo: Saraiva Educação, 2018.

NEVES, D. A. A. Manual de direito processual civil - Volume único. Salvador: JusPodivm, 2016.

OLIVEIRA, R. D.; RIBAS, C. Migalhas, 13 maio 2015. Disponivel em:

<https://www.migalhas.com.br/depeso/220354/as-causas-de-dissolucao-parcial-da-sociedadeempresaria-limitada>. Acesso em: 14 ago. 2020.

PEDRON, F. Q.; CAZASSA, L. D. P. S. O procedimento especial de dissolução parcial de sociedade no Código de. Revista Brasileira de Direito Processual - RBDPro, Jan - Mar 2017.

PEREIRA, J. B. B. DA SOCIEDADE COOPERATIVA. Revista do Tribunal Superior do Trabalho, vol. 69, p. 32-54, Jul.-Dez. 2003.

PIMENTA, L. Empresarial para quem odeia empresarial. São Paulo: Saraiva, 2015.

RAMOS, A. L. S. C. Direito Empresarial Esquematizado. São Paulo: Método, 2015.

RIBEIRO, C.; MENEZES, P. Academia.edu, 2014. Disponivel em:

<https://www.academia.edu/32438027/TEORIA_GERAL_DO_DIREITO_EMPRESARIAL_AUTORAS_CL \%C3\%81UDIA_RIBEIRO_E_PRISCILLA_MENEZES> Acesso em 20 de maio de 2020.

ROVAI, A.; SALLES, P. S. N. J. DOS NOVOS PARADIGMAS DA AÇÃO DE DISSOLUÇÃO PARCIAL DE. Revista dos Tribunais Online, vol.75, p. 117-128, Jan- Mar. 2017.

SANTOS, E. T. V. D. Direito Empresarial. São Paulo: Revista dos Tribunais, 2012.

SOLER, J. L. A QUEBRA DA AFFECTIO SOCIETATIS NA EXCLUSÃO DE SÓCIOS E. Revista dos Tribunais Online, vol.957, p. 177-198, Jul. 2015.

TEIXEIRA, T. Direito empresarial sistematizado: doutrina, jurisprudência e prática. São Paulo: Saraiva Educação, 2018. 


\section{Affectio Societatis Na Dissolução De Sociedade Limitada}

THEODORO, H. J. Curso de Direito Processual Civil - Procedimentos Especiais - vol. II. Rio de Janeiro: Forense, 2016.

TOMAZETTE, M. Curso de Direito Empresarial: Teoria Geral e direito societario, v.1. São Paulo: Atlas, 2017.

WALD, A. ATUALIDADES DA SOCIEDADE EM CONTA DE PARTICIPAÇÃO SOB NOVA. Revista dos Tribunais Online, vol.13, p.71-78, Jan - Fev. 2016. 